\title{
Nogo Receptor Homolog NgR2 Expressed in Sensory DRG Neurons Controls Epidermal Innervation by Interaction with Versican
}

\author{
Bastian E. Bäumer, ${ }^{1}$ Antje Kurz, ${ }^{1}$ Sarah C. Borrie, ${ }^{1}$ Stephan Sickinger, ${ }^{1}$ María T. Dours-Zimmermann, ${ }^{2}$ \\ Dieter R. Zimmermann, ${ }^{2}$ and Christine E. Bandtlow ${ }^{1}$ \\ ${ }^{1}$ Division of Neurobiochemistry, Biocenter, Innsbruck Medical University, 6020 Innsbruck, Austria and 2Institute of Surgical Pathology, University Hospital \\ Zurich, 8091 Zurich, Switzerland
}

Primary sensory afferents of the dorsal root ganglion (DRG) that innervate the skin detect a wide range of stimuli, such as touch, temperature, pain, and itch. Different functional classes of nociceptors project their axons to distinct target zones within the developing skin, but the molecular mechanisms that regulate target innervation are less clear. Here we report that the Nogo66 receptor homolog $\mathrm{NgR} 2$ is essential for proper cutaneous innervation. NgR2 ${ }^{-1-}$ mice display increased density of nonpeptidergic nociceptors in the footpad and exhibit enhanced sensitivity to mechanical force and innocuous cold temperatures. These sensory deficits are not associated with any abnormality in morphology or density of DRG neurons. However, deletion of NgR2 renders nociceptive nonpeptidergic sensory neurons insensitive to the outgrowth repulsive activity of skin-derived Versican. Biochemical evidence shows that NgR2 specifically interacts with the G3 domain of Versican. The data suggest that Versican/NgR2 signaling at the dermo-epidermal junction acts in vivo as a local suppressor of axonal plasticity to control proper density of epidermal sensory fiber innervation. Our findings not only reveal the existence of a novel and unsuspected mechanism regulating epidermal target innervation, but also provide the first evidence for a physiological role of $\mathrm{NgR} 2$ in the peripheral nervous system.

\section{Introduction}

Sensory neurons of the dorsal root ganglion (DRG) that innervate the skin allow the detection of mechanical, thermal, itchy, and painful sensations. These different sensory modalities are reported to postsynaptic neurons in the spinal cord and subsequently to the brain. In adult mice, two of the major subpopulations of DRG sensory neurons are specialized for nociception. They exhibit different molecular characteristics and require different target-derived trophic factors for their survival, differentiation and maintenance (Basbaum et al., 2009). Peptidergic nociceptors express the neuropeptide calcitonin gene-related peptide (CGRP) and respond to nerve growth factor (NGF), whereas nonpeptidergic nociceptors express the purinergic receptor P2X3, bind the isolectin B4 (IB4), and respond to glialderived neurotrophic factor (GDNF) family ligands (GFLs; Molliver et al., 1995; Priestley et al., 2002). Anatomically, axons of

Received July 2, 2013; revised Nov. 21, 2013; accepted Dec. 16, 2013.

Author contributions: B.E.B. and C.E.B. designed research; B.E.B., A.K., S.C.B., and S.S. performed research; M.T.D.-Z., D.R.Z., and C.E.B. contributed unpublished reagents/analytic tools; B.E.B., S.C.B., S.S., and C.E.B. analyzed data; B.E.B., D.R.Z., and C.E.B. wrote the paper.

This work was supported by the Austrian Research Foundation (FWF W1206) and by support of the IFTZ of Innsbruck Medical University to C.E.B. We thank Sandra Trojer, Sabrina Riepler, and Augustine Boima for technical assistance, animal husbandry, and genotyping support; Martin Offterdinger for valuable help with confocal microscopy and 3D reconstructions; and the Ginty lab for advice for ISH.

This article is freely available online through the J Neurosci Author Open Choice option.

Correspondence should be addressed to Christine E. Bandtlow, Innsbruck Medical University, Biocenter, Division of Neurobiochemistry, Innrain 80, A-6020 Innsbruck, Austria. E-mail: christine.bandtlow@i-med.ac.at.

DOI:10.1523/JNEUROSCI.3094-13.2014

Copyright $\odot 2014$ the authors $\quad 0270-6474 / 14 / 341633-14 \$ 15.00 / 0$ both populations of DRG neurons terminate in different central and peripheral target layers (Zylka et al., 2005), suggesting that they exhibit distinct functional properties. Although targetderived neurotrophic factors control at large epidermal fiber density, repulsive cues such as semaphorins, ephrins or extracellular matrix (ECM) molecules at the dermo-epidermal junction (DEJ) may also have instructive roles in targeting decisions (Moss et al., 2005; Tominaga et al., 2008; Chiang et al., 2011). Prominent components of the skin ECM are the chondroitin-sulfate proteoglycans (CSPG) Versican V0 and V1 (Zimmermann et al., 1994), which act as repellent factors to sensory axons in vitro (Dutt et al., 2011), suggesting that their biological function may be to prevent sensory axons from crossing into inappropriate territory. As abnormalities in sensory innervation are often associated with abnormal perception of itch and pain, a detailed understanding of the molecular mechanisms involved in establishing and maintaining correct nociceptive innervation is of considerable interest.

$\mathrm{NgR} 2$ is a member of the Nogo66 receptor NgR family that consists of three structurally related proteins, NgR1-3 (Laurén et al., 2003). NgR1 and NgR2 were identified as axonal glycosylphosphatidylinositol-anchored proteins with specific binding properties for myelin-associated growth inhibitors in the CNS (Fournier et al., 2001; Wang et al., 2002; Venkatesh et al., 2005). In addition, $\mathrm{NgR} 1$ and $\mathrm{NgR} 3$, but not $\mathrm{NgR} 2$, were shown to associate with selective glycosaminoglycan (GAG) side chains of CSPGs (Dickendesher et al., 2012). NgRs, in particular NgR1, have attracted considerable interest because of their suggested 
role in restricting axon collateral sprouting after injury and limiting structural synaptic plasticity in the intact CNS (Mironova and Giger, 2013). However, examining the functional relevance of NgR2 in vivo has proven challenging because of the potential redundancy with other NgRs (Wörter et al., 2009, Wills et al., 2012) and the lack of unequivocally identified specific ligands.

We show that NgR2 on sensory DRG neurons is required for proper skin innervation. $\mathrm{NgR} 2^{-1-}$ mice display increased afferent density of nonpeptidergic nociceptors in the footpad, accompanied by increased responses to noxious mechanical forces and innocuous cold sensation. NgR2 binds to the protein core of Versican and is necessary to render nonpeptidergic sensory neurons sensitive to Versican inhibition. Our data suggest that NgR2/ Versican signaling acts to locally suppress sensory terminal branching at the DEJ.

\section{Materials and Methods}

\section{Plasmids}

Full-length human myelin oligodendrocyte glycoprotein (MOG) cDNA was kindly provided by Markus Reindl, Innsbruck. Untagged human Versican V0 and V1 plasmids (Dours-Zimmermann and Zimmermann, 1994) and Nogo-myc (Oertle et al., 2003) have been described. Fulllength human Versican V3 cDNA was generated by reverse transcription (RT)-PCR from primary cultured fibroblasts with the primers: forward 5' -AAGAAGGCCCAGCCGGCCCTACATAAAGTCAAAGTGGGA-3'; reverse 5' -AAGAATCTAGACCGGCCCTCGATGCGCCTCGACTC-3'. The resulting product was cloned into SfiI/XbaI digested $\mathrm{pSecTag-A} \mathrm{vec-}$ tor (Invitrogen). The final construct carries a Factor Xa cleavage site at the $3^{\prime}$ end, followed by myc- and 6xHis-tags from the vector.

Versican constructs encompassing either of the globular domains G1 (ENSEMBL VCAN-005 ENST00000502527 c.VCAN V3 nucleotides 60 1041) or G3 (nucleotides 1043-1966) were prepared analogously using the human Versican V3 (Zako et al., 1995) construct as template. The primers for the PCR amplification of G1 were as follows: forward 5' ATAGGCCCAGCCGGCCCTACATAAAGTCAAAGTG-3'; reverse 5' CCGTCTAGATTTAAAGCAGTAGGCATC-3' and for G3: forward 5'-ATAGGCCCAGCCGGCCGGACCTGATCGCTGCAAA-3' and reverse $5^{\prime}$-CCGTCTAGAGCGCCTCGACTCCTGCCA-3'. PCR products were cloned into the pSecTag (Invitrogen). NgR2-mFc encompassing the ectodomain of mouse NgR2 including the signal peptide (nucleotides 1-1168; forward 5'-TATAAGCTTACCATGCTGCCCGGGCTCC GGC-3' and reverse 5'-TATGCGGCCGCCACGCGGCCCCGGGA CACGTCTG-3') was generated by PCR amplification and cloned into pCMV6-AC-Fc (OriGene) using the HindIII-NotI sites of the vector. To generate $\mathrm{NgR} 2-\mathrm{hFc}$, the murine Fc-tag was replaced with the human $\mathrm{Fc}$-tag using the XhoI-FseI sites of the vector. The following primers were used: forward 5'-CCGCTCGAGCCCAAATCTTGT-3' and reverse 5'GTAGGCCGGCCTCATTTACCCGGAGA-3'. Restriction sites used for subcloning are underlined. All constructs were verified by sequencing analysis (LGC).

\section{Animals and ethics statement}

NgR2-null mice have been described previously (Wörter et al., 2009). Wild-type (WT) littermate controls and $\mathrm{NgR} 2^{-1-}$ animals were obtained by mating heterozygous $\mathrm{NgR} 2^{+/-}$animals. All animal experiments have been performed with permission of the Austrian Federal Ministry for Science and Research (ref. BMWF-66.011/0085-C/GT/ 2007) and in accordance with the ethical guidelines of the International Association for the Study of Pain.

Nociceptive tests were performed as described previously (Lagerström et al., 2011). Adult (>8 weeks) male $\mathrm{NgR} 2^{-1-}$ mice $(n=8)$ and WT littermate controls $(n=8)$ from an inbred colony in a C57BL/6J background were used in the experiments. Mice were housed on a $12 \mathrm{~h} \mathrm{light/}$ dark cycle with mouse chow and water ad libitum. All behavioral studies were conducted as blind experiments.

Randall-Selitto test. The test was performed on one mouse at a time as described previously (Lagerström et al., 2011). Mice were trained for $2 \mathrm{~d}$ and tested on the third day. The hindpaw was gently placed under the
Randall-Selitto arm (Ugo Basile) before an increasing weight was applied to the paw. The cutoff was set to $250 \mathrm{~g}$. The weight at which the mouse withdrew its paw was recorded and the result expressed as the mean withdrawal latency in grams for each animal and group \pm SEM. Statistical significance was determined by a Mann-Whitney $U$ test.

Hot-plate test. Mice were acclimatized to the hot plate (Ugo Basile) at room temperature $\left(21^{\circ} \mathrm{C}\right)$ for $5 \mathrm{~min}$ the day before testing. On the test day, the latency of withdrawal of the hindpaw at $56^{\circ} \mathrm{C}$ followed by lifting, licking, or biting of the paw was measured as described previously (Lagerström et al., 2011). Results are expressed as mean withdrawal latency for each animal and group \pm SEM. Statistical significance was determined by a Mann-Whitney $U$ test.

Cold-plate test. Mice were acclimatized to the plate $\left(21^{\circ} \mathrm{C}\right)$ for $5 \mathrm{~min}$ the day before testing. On the test day, the plate was cooled to $10^{\circ} \mathrm{C}$ and hindpaw lifts not associated with general movement were recorded as response over $5 \mathrm{~min}$. Results are expressed as mean withdrawal latency for each animal and group \pm SEM. Statistical significance was determined by a Mann-Whitney $U$ test.

Thermal preference test. Mice were placed into a chamber consisting of two adjacent metal plates at controlled temperatures (Ugo Basile) and allowed to explore the test arena with both surfaces set at $30^{\circ} \mathrm{C}$ for $5 \mathrm{~min}$ the day before testing. Preference testing was performed as described by holding one plate at a constant temperature of $30^{\circ} \mathrm{C}$, and the other ranged in temperature from 10 to $30^{\circ} \mathrm{C}$ in $5^{\circ} \mathrm{C}$ steps (test plate; Bautista et al., 2007). To assess the avoidance of heat one assay was performed with the test plate set at $49^{\circ} \mathrm{C}$. Voluntary movement of mice between plates was recorded over $5 \mathrm{~min}$ by tallying the cumulative time spent on each plate. Data are expressed as the percentage of time in seconds spent on the $30^{\circ} \mathrm{C}$ plate over a 5 min period for each animal and group \pm SEM. Statistical significance was determined by a Mann-Whitney $U$ test at each temperature.

\section{In situ hybridization}

An 800 bp RT-PCR product corresponding to nucleotides 481-1263 of murine NgR2 was cloned into pBluescript and pCRII-TOPO vector, respectively. Sense and antisense cRNA probes were transcribed by T7 and T3 RNA polymerases, respectively. Transcription reactions took place in the presence of digoxigenin (DIG)-uridine triphosphate using a DIG RNA labeling kit (Roche Diagnostics) according to the manufacturer's instructions. Cryostat sections $(20 \mu \mathrm{m})$ from lumbar DRGs (L4-L5) were obtained from adult C57BL/6 mice, thawed on poly-lysine-coated slides (Thermo Scientific), and fixed with $2 \%$ paraformaldehyde (PFA) in PBS at $4^{\circ} \mathrm{C}$ for 15 min. In situ hybridization (ISH) was performed as described previously (Bourane et al., 2007). After permeabilization with $0.05 \mathrm{M} \mathrm{HCl}$ and acetylation with $0.25 \%$ acetic anhydrate in $0.1 \mathrm{~m}$ triethanolamine, sections were hybridized with DIG-labeled riboprobes $(1 \mathrm{ng} / \mu \mathrm{l})$ overnight at $70^{\circ} \mathrm{C}$. After washing with $1 \times$ SSC, $50 \%$ formamide, $0.1 \%$ Tween at $65^{\circ} \mathrm{C}$, and with $100 \mathrm{~mm}$ maleic acid, $150 \mathrm{~mm} \mathrm{NaCl}$, and $0.1 \%$ Tween at room temperature, sections were blocked with $10 \%$ normal goat serum and $1 \%$ blocking reagent (Roche) in PBS. Hybridized probes were detected with anti-DIG-alkaline phosphatase antibody (1:1000; Roche) and developed as recommended by the manufacturer's instructions (Roche DIG labeling detection kit). To ensure equivalent conditions sense and antisense riboprobes were used at equivalent concentrations and run in parallel in the same experiments.

\section{Expression and purification of recombinant proteins}

$\mathrm{CHO}$ cells expressing secreted NgR2-mFc, NgR2-hFc, and Fc control proteins were grown for 2 weeks to high density, then the media were collected and filtered through a $0.45 \mu \mathrm{m}$ filter. Recombinant Fc-fusion proteins were purified as previously described (Niederöst et al., 2002). Protein concentration was determined by the Bradford assay and protein purity was confirmed by silver staining. Sema3A-mFc and Ephrin4A-hFc were purchased (R\&D Systems). Recombinant untagged human Versican V0 and Versican V1 were produced by transient transfection of $\mathrm{CHO}-\mathrm{K} 1 \mathrm{using}$ jetPEi transfection reagent (Polyplus). After $36 \mathrm{~h}$ in culture, cells were harvested by centrifugation and lysed with radioimmunoprecipitation assay buffer $(25 \mathrm{~mm}$ Tris- $\mathrm{HCl}, 150 \mathrm{~mm} \mathrm{NaCl}, 1 \%$ 
A

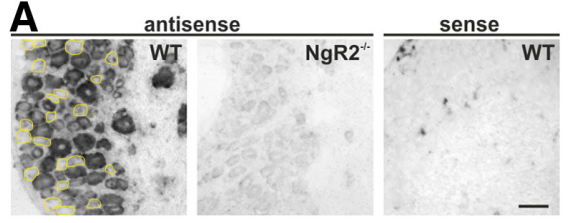

B
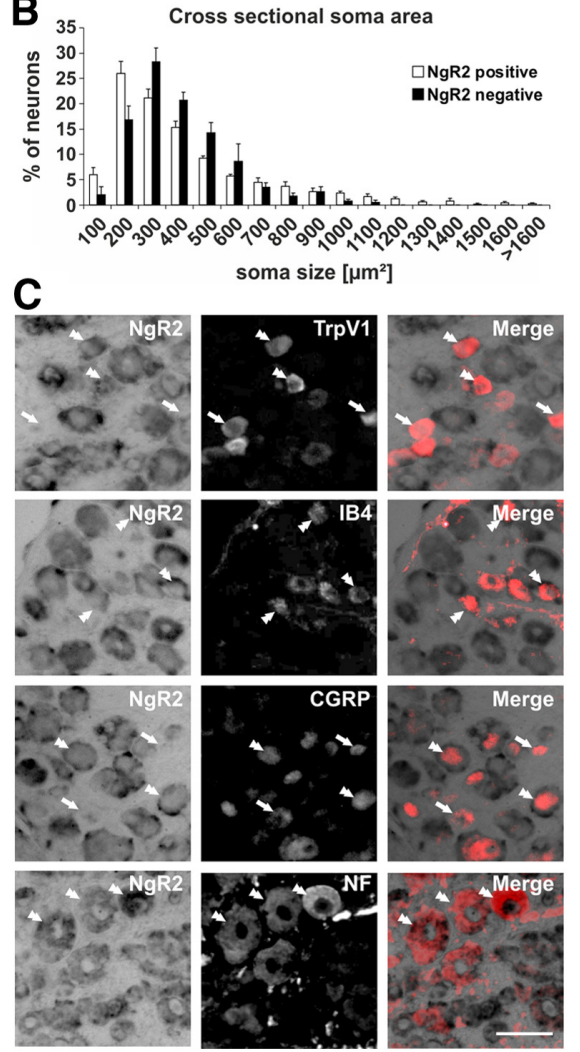
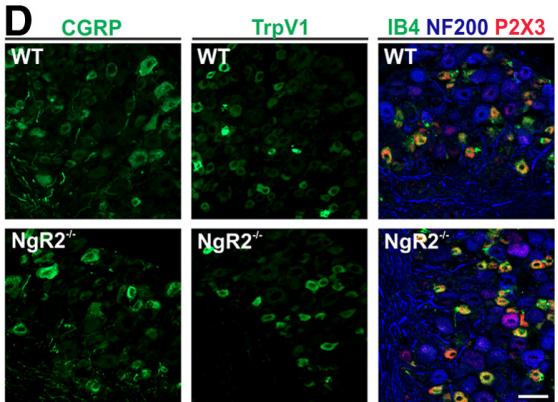

E

\begin{tabular}{l|c|c}
$\begin{array}{l}\text { Percentage of } \\
\text { immunopositive } \\
\text { cell bodies }\end{array}$ & WT & NgR2 $^{-/ .}$ \\
\hline IB4 & $33.84 \pm 1.79$ & $33.12 \pm 1.93$ \\
NF200 & $50.87 \pm 3.63$ & $52.42 \pm 2.33$ \\
CGRP & $40.87 \pm 4.83$ & $41.30 \pm 4.43$ \\
TrpV1 & $23.77 \pm 1.06$ & $23.62 \pm 1.60$ \\
P2X3 & $36.04 \pm 1.51$ & $35.19 \pm 1.71$ \\
P2X3/IB4 & $33.28 \pm 0.93$ & $32.32 \pm 1.27$
\end{tabular}

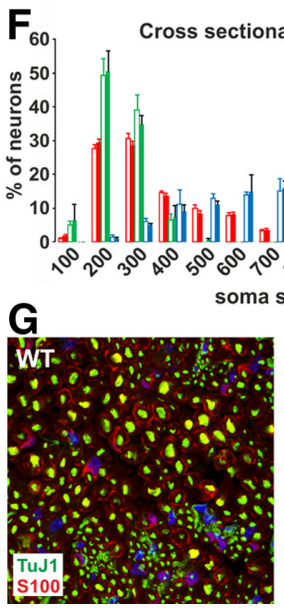

Figure 1. NgR2 is expressed by distinct subpopulations of sensory neurons. $A$, Representative DRG cross sections of WT and $\mathrm{NgR2}{ }^{-1-}$ mice labeled with antisense and sense cRNA probes against NgR2-mRNA. NgR2-negative neurons are encircled by a yellow line. $\boldsymbol{B}$, Size distribution of NgR2 mRNA-positive and -negative cells in adult DRG. $\boldsymbol{C}$, Combined ISH of NgR2 mRNA with IHC (red) for indicated markers. Arrowheads mark double-labeled neurons; arrows indicate marker-positive but NgR2-negative neurons. $\boldsymbol{D}$, Confocal micrographs of L5 DRG sections from WT and NgR2 ${ }^{-1-}$ mice stained for CGRP and TrpV1 (both green) or triple-stained for IB4 (green), P2X3 (red), and NF200 (blue). E, Proportion of neurons stained for indicated markers was similar in $\mathrm{NgR2}{ }^{-1-}$ and WT controls. $(p>0.05 ; n=4) . \boldsymbol{F}$, Size-frequency histogram illustrating the distribution of the cross-sectional areas of DRG neurons positive for the indicated markers in WT and $\mathrm{NgR2}^{-1-}$ mice. Note that the frequency distribution of marker-expressing neurons is unaffected in NgR2 ${ }^{-1-}$ mice. G, Confocal micrographs of sciatic nerve cross sections from WT and $\mathrm{NgR2}{ }^{-/-}$mice double stained for the Schwann cell marker $\mathrm{S} 100 \beta$ (red) and TuJ1 (green). Morphology appeared equal for $\mathrm{NgR2}{ }^{-1-}$ and WT littermate controls. Scale bars: $A, C, D, G, 40 \mu \mathrm{m}$.

Nonidet P-40, and $0.1 \%$ SDS) containing protease inhibitors (Roche). The lysate was cleared by centrifugation $\left(14,000 \times g\right.$ for $20 \mathrm{~min}$ at $\left.4^{\circ} \mathrm{C}\right)$ and the supernatant was diluted to $100 \mu \mathrm{g} / \mathrm{ml}$ total protein before use for stripe coating in cell culture experiments described below. Recombinant human Versican V3 was produced as myc-His $_{6}$ fusion proteins by transient transfection of $\mathrm{CHO}-\mathrm{K} 1$ using jetPEi transfection reagent (Polyplus). Conditioned medium and $1 \mathrm{M} \mathrm{NaCl}$ cell extracts were incubated with nickel-agarose beads (Clontech) for $4 \mathrm{~h}$ at $4^{\circ} \mathrm{C}$. After washing with PBS containing $10 \mathrm{~mm}$ imidazole, bound proteins were eluted with PBS containing $500 \mathrm{~mm}$ imidazole. Purity of proteins was determined by SDS-PAGE followed by silver staining and Western blot analysis with anti-myc antibody (Sigma-Aldrich). Protein concentration was determined by the Bradford assay.

\section{Quantitative real-time PCR}

Total RNA was isolated by homogenizing frozen lumbar DRGs and glabrous skin from the hindpaw of WT and $\mathrm{NgR} 2^{-1-}$ mice, using the Macherey-Nagel NucleoSpin RNA II Kit according to the manufacturer's instructions including DNase I digestion. RNA integrity and concen- tration were determined by agarose gelelectrophoresis and by UV absorbance using a NanoDrop 2000 spectrophotometer (Thermo Scientific). One to two micrograms of total RNA was reverse transcribed using RevertAid First Strand cDNA Synthesis Kit (Fermentas). Quantitative real-time ( $\mathrm{qRT}$ )-PCR was performed in a $20 \mu \mathrm{l}$ reaction containing $4 \mu \mathrm{l}$ of the $1: 5$ or $1: 10$ diluted reverse transcribed reaction, $0.5 \mu \mathrm{M}$ of each primer (Metabion) and 10 $\mu \mathrm{l} 2 \times$ SsoFast EvaGreen Supermix (Bio-Rad). Reactions were run in triplicate on an Applied Biosystems 7500 Fast Cycler. After amplification, a dissociation curve was plotted against melting temperature to ensure amplification of a single product. Control reactions for every amplification were run without template and with the reverse transcriptase control reaction products as negative controls. Normalized fold expression of the target gene (i.e., the effect in NgR2 ${ }^{-1}$ mice) was calculated according to the $\Delta \Delta \mathrm{Ct}$ method (Livak and Schmittgen, 2001). Fold change in the amount of target mRNA was normalized to the housekeeping gene RPS29. Means of the $\Delta \mathrm{Ct}$ values of four $\mathrm{NgR} 2^{+/+}$and four $\mathrm{NgR} 2^{-1-}$ mice were used to calculate the $\Delta \Delta \mathrm{Ct}$ value $(\Delta \Delta \mathrm{Ct}=\Delta \mathrm{Ct}$ $\left.\mathrm{NgR} 2^{-1-}-\Delta \mathrm{Ct} \mathrm{NgR} 2^{+/+}\right)$. The SDs of the fold changes were calculated according to the Guide to Performing Relative Quantitation of Gene Expression Using Real-Time Quantitative PCR (Applied Biosystems) and are expressed as the range of fold difference. Intron-spanning primer pairs for murine Neurturin (NTN), GFR $\alpha 3$, TrkA, TrkB, and TrkC were designed using Primer BLAST (National Center for Biotechnology Information, NCBI). Specificity was confirmed by BLAST (NCBI). Possible dimer formation was analyzed by FastPCR (www. biocenter.helsinki.fi/bi/programs/fastpcr.htm).

Primer sequences for GFRa1, GFRa2, NGF, BDNF, GDNF, and NT3 were taken from Jankowski et al. (2009), and for both isoforms of c-Ret from Kojima et al. (2011). Primer sequences for Asicla and Asic2a were taken from Sherwood et al. (2011), and for Asic3a from Hattori et al. (2009). Additional primers were used for: NTN (forward: 5' -AGCTCCCTGCTATCTGTCTGGATG-3'; reverse: $5^{\prime}$-GAGAA AGTTCTCGAAGCTCCACC- $3^{\prime}$ ); GFR $\alpha 3$ (forward: 5'-CTTGGTGACTACGAGTTGGATGTC3'; reverse: 5'-AGATTCATTTTCCAGGGTTTGC-3'), TrkA (forward: 5'-AGGTCTCTGTCCAAGTCAGCGTC-3'; reverse: 5'-TCTCGTTGAGCA CAGAGCCGTT-3'); TrkB (forward: 5'-TGCACGCAAGGACTTTCATC GGGA-3'; reverse: $5^{\prime}$-TGTTGGGACGCCAGGTAGACCATA-3'); TrkC (forward: 5'-AGGTCTTCCTGGCTGAGTGCTACAA-3'; reverse: 5'-AGGC TATCTGACTGGCGATGTGGA-3').

Preparation of protein-coated beads and bead aggregation assay Bead-cell adhesion and bead aggregation assays were performed as previously described (Marthiens et al., 2005). Aliquots of $100 \mu$ l carboxylate microsphere suspension $\left(3 \times 10^{8}\right.$ microspheres $/ \mathrm{ml}$, diameter $4.5 \mu \mathrm{m}$; Polysciences) were washed with $0.1 \mathrm{~m}$ borate buffer, $\mathrm{pH} 8$, and incubated overnight at $4^{\circ} \mathrm{C}$ with $20 \mu \mathrm{g}$ of either goat anti-mouse IgG, Fc fragmentspecific antibody (Jackson ImmunoResearch) or VersicanV0/V1-specific rabbit anti-GAG $\beta$ antibodies. Beads were saturated with $1 \%$ bovine serum albumin (BSA) in borate buffer for 15 min. Anti-mouse-Fc beads were incubated under mixing with $1 \mu \mathrm{g}$ of NgR2-mFc, Sema3A-mFc, or control $\mathrm{mFc}$. Beads coupled with anti-GAG $\beta$ were incubated with lysates 
A
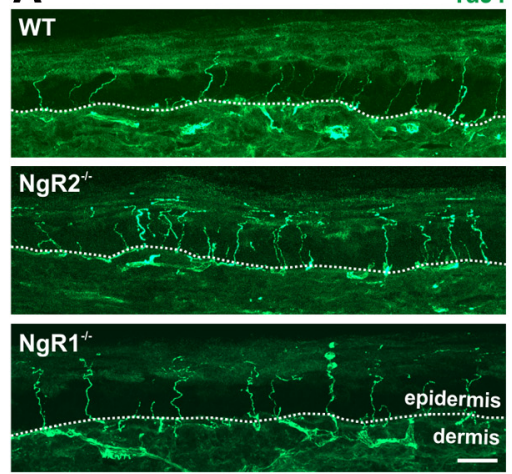

E
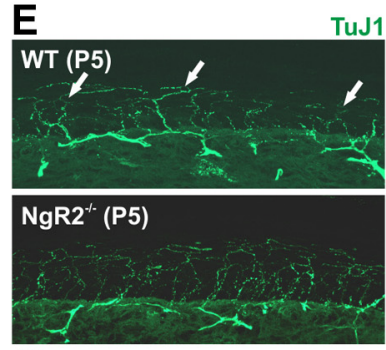

G

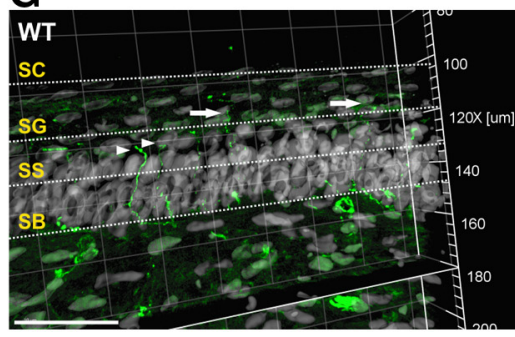

B
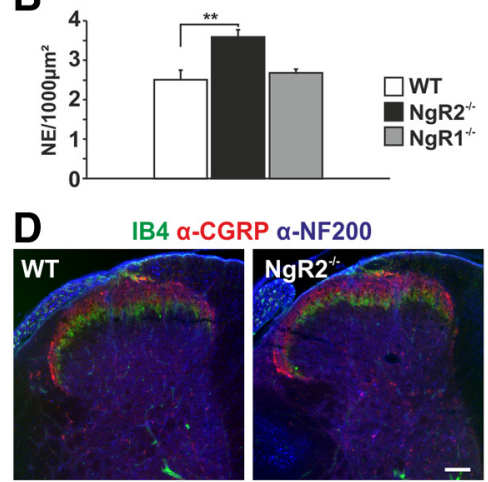

a-CGRP
C $\alpha-\mathrm{NF}$
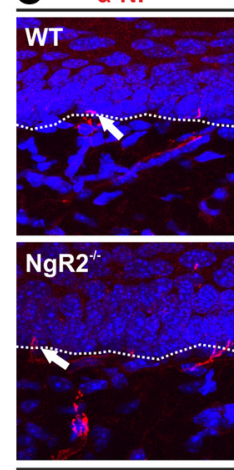

NF terminals merge

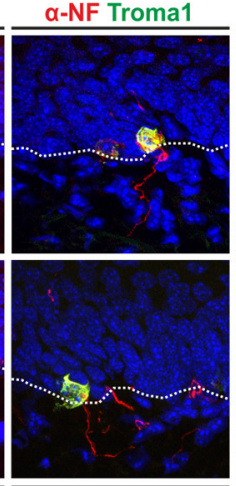

F

Merkel cells

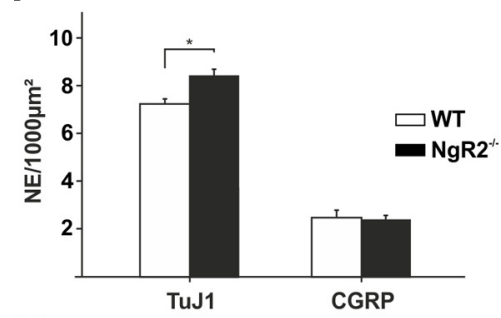

H

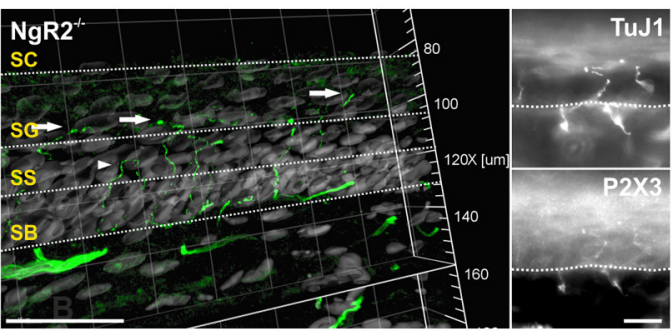

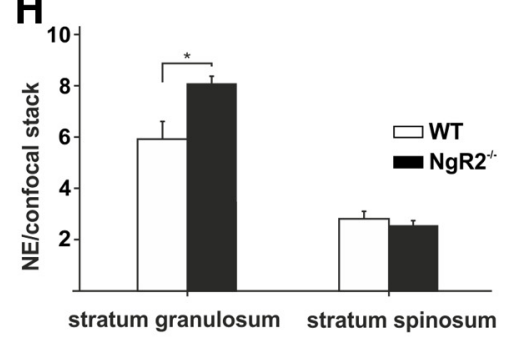

Figure 2. NgR2-deficient mice display epidermal hyperinnervation of nonpeptidergic fibers. $A$, Cross sections of the glabrous hindpaw skin of adult WT, $\mathrm{NgR2}{ }^{-/-}$, and NgR1 ${ }^{-/-}$mice stained with TuJ1. Dotted line denotes DEJ. $\boldsymbol{B}$, Quantification of the total number of TuJ ${ }^{+}$nerve endings (NE) per $1000 \mu \mathrm{m}^{2}$ skin area $\left({ }^{* *} p<0.01 ; n=5\right.$ for each genotype). C, Confocal analysis of Troma-I-labeled MCs (green) or of S100-positive Meissner's corpuscles (green) innervated by neurons as labeled by NF200 (red). Sections were counterstained with Hoechst (blue). Dotted line denotes DEJ. D, L5 spinal cord cross sections from WT and NgR2 ${ }^{-1-}$ mice show no difference in density and termination pattern of CGRP ${ }^{+}$(red), IB4 ${ }^{+}$(green), and NF200 ${ }^{+}$(blue) primary afferents in the superficial layers of the dorsal horn. $E$, Cross sections of the glabrous hindpaw skin of P5 WT and NgR2 ${ }^{-1}$ mice stained for TuJ1 (green) and (GRP (red). Arrows mark double-labeled fibers. $\boldsymbol{F}$, Total number of TuJ1 ${ }^{+}$nerve endings per $1000 \mu \mathrm{m}^{2}$ skin area is significantly increased in $\mathrm{p5} \mathrm{NgR2}^{-1-}$ mice $\left.{ }^{*} p<0.05 ; n=4\right)$, while the number of (GRP ${ }^{+}$fibers is unaltered. G, $3 \mathrm{D}$ reconstruction of $20 \mu \mathrm{m}$ confocal stacks. Nuclei were counterstained with Hoechst. Arrows indicate TuJ $1^{+}$terminals in stratum granulosum (SG), arrowheads in stratum spinosum (SS). TuJ1 ${ }^{+}$ fibers terminating in stratum granulosum coexpress $\mathrm{P} 2 \mathrm{X} 3$ (small images). $\boldsymbol{H}$, Quantification of TuJ ${ }^{+}$nerve endings shows that significantly more nociceptive fibers terminated in the stratum granulosum in NgR2 ${ }^{-/-}$mice than in WT mice $\left.{ }^{*} p<0.05 ; n=4\right)$. Scale bars: $A, C, D, E, 40 \mu \mathrm{m}$. SB, stratum basalis; $S C$, stratum corneum.

of Versican V0 or V1-expressing CHO cells (10 $\mu$ g total protein) for $1 \mathrm{~h}$ at room temperature. Purified Aggrecan ( $5 \mu \mathrm{g}$; Millipore) or human MAG ( $5 \mu \mathrm{g}$; Sino Biologicals) was directly coupled to $50 \mu \mathrm{l}$ beads in $0.1 \mathrm{M}$ borate buffer, $\mathrm{pH} 8$. To quantify amounts of immobilized protein, $20 \mu \mathrm{l}$ of coated beads were heated $\left(85^{\circ} \mathrm{C}, 10 \mathrm{~min}\right)$ in Laemmli buffer and the supernatant was used for SDS-PAGE with NuPAGE 4-12\% Bis-Tris gels (Invitrogen). Gels were silver stained or transferred to PVDF membranes for Western blots using anti-mFc-Cy3 antibodies. Bands were detected using SuperSignal West Pico chemiluminescent substrate (Thermo Fisher Scientific) and quantified using ImageJ (version 1.44o). For the bead-cell adhesion assay, $\mathrm{CHO}$ cells were seeded on $10 \mathrm{~mm}$ glass coverslips in 48-well plates and transiently transfected with pSecTagVersicanV0, pSecTag-VersicanV1, or pSecTag-VersicanV3 constructs. Cells were cultivated for $36 \mathrm{~h}$ before by addition of $2.5 \mu \mathrm{l}$ coated beads in $250 \mu \mathrm{l}$ DMEM to each well. Beads were allowed to bind for $45 \mathrm{~min}$ at $37^{\circ} \mathrm{C}, 5 \% \mathrm{CO}_{2}$. After washing, cells were fixed for $15 \mathrm{~min}$ with $2 \%$ PFA in $\mathrm{PBS}$ and used for immunostaining of Versican V0/V1 (rabbit anti human GAG $\beta ; 1: 2000)$ isoforms as described above. Versican V3 was visualized through the myc-tag with mouse anti-myc (1:2000; Sigma-Aldrich). For bead aggregation assays, beads ( $1 \mu$ l each in $250 \mu$ l DMEM) coupled with $\mathrm{NgR} 2-\mathrm{mFc}$, Sema3A-mFc, or mFc were mixed with beads coupled with recombinant Versican V0, Versican V1, Aggrecan, or MAG (each $1 \mu \mathrm{l}$ in
$250 \mu$ l DMEM) and allowed to settle on a glass coverslip in a 48-well format for $45 \mathrm{~min}$ at $37^{\circ} \mathrm{C}$. Where indicated, the assay was performed with Versican-coupled beads pretreated for $3 \mathrm{~h}$ at $37^{\circ} \mathrm{C}$ with $0.1 \mathrm{U}$ Chondroitinase ABC (Sigma-Aldrich). The aggregation index was determined as (number of counted beads - number of beads in aggregates)/number of counted beads. For each experiment $(n)$, five fields each containing $\sim 1000$ beads were analyzed. Statistical analysis used unpaired Student's $t$ tests (GraphPad Prism, version 5), with statistical significance reported in the figure legends.

\section{Coimmunoprecipitation and immunoblotting}

$\mathrm{CHO}-\mathrm{K} 1$ cells were cotransfected with the NgR2-hFc or hFc expression vector in combination with human full-length Versican V3-pSectag, G1pSectag, G3-pSectag, or NogoB-pcDNA3.1. Twenty-four hours after transfection, cells were lysed in precipitation buffer $(50 \mathrm{~mm}$ Trisphosphate, pH 7.4, containing $150 \mathrm{~mm} \mathrm{NaCl}, 0.2 \%$ Nonidet P-40, 1\% BSA, $1 \mathrm{~mm}$ phenylmethylsulfonyl fluoride, and $2 \mathrm{mg} / \mathrm{ml}$ aprotinin) and centrifuged at $14,000 \times g$ for $20 \mathrm{~min}$ at $4^{\circ} \mathrm{C}$. The cell lysate was combined with the conditioned medium and incubated for $2 \mathrm{~h}$ at $4^{\circ} \mathrm{C}$ with protein A/G-agarose beads. Beads were washed three times with PBS before the separation of bound proteins by SDS-PAGE. Immunoblots were probed using a monoclonal anti-hFc-Cy3 antibody (Sigma-Aldrich) to detect 
hFc only and NgR2-hFc and an anti-myc antibody (Sigma-Aldrich) was used to detect the full-length Versican V3, the N-terminal G1, the C-terminal G3, and the full-length NogoB. Membranes were washed with TBS-T, incubated with appropriate secondary antibodies, and developed with the Odyssey scanning system (Odyssey CLx; LI-COR). Secondary antibodies included anti-mouse-IRDye680 (1:20.000; LI-COR) and anti-rabbit-IRDye800 (1:20.000; LI-COR).

Immunohistochemistry. Lumbar DRGs (L4-L5), sciatic nerve, and glabrous hindpaw skin were dissected and fixed for up to $4 \mathrm{~h}$ in $4 \%$ PFA in PBS, then cryoprotected in $25 \%$ sucrose in PBS at $4^{\circ} \mathrm{C}$ for at least $24 \mathrm{~h}$ and embedded and frozen in optical cutting medium (OCT; Richard-Allan Scientific). Spinal cord samples were dissected and immediately snap frozen with liquid nitrogen. Cryostat sections of $12 \mu \mathrm{m}$ for DRGs and sciatic nerve and $20 \mu \mathrm{m}$ for skin and spinal cord were mounted on poly-lysine-coated slides (Thermo Scientific) and blocked in 10\% normal goat serum in PBS containing 0.3\% Triton X-100 (PBST) for $1 \mathrm{~h}$, reacted with primary antibodies at room temperature for $12 \mathrm{~h}$, washed, and incubated $90 \mathrm{~min}$ at room temperature with secondary antibodies. Primary antibodies included: goat anti-CGRP (1:300; Abcam), mouse anti-NF200 (1:1000; Sigma-Aldrich), chicken anti-NF (1:1000; gift from Michaela Kress, Innsbruck Medical University), rat anti-cytokeratin 8 (clone Troma-I, 1:40; Developmental Studies Hybridoma Bank), guinea pig anti-P2X3 (1:1000; Millipore), rabbit anti-TrpV1 (1:2000; a gift from Hans-Günther Knaus, Innsbruck Medical University, Austria), mouse anti- $\beta$-III-tubulin (clone TuJ1, 1:1000; R\&D Systems), rabbit anti-S100 (1:1000; Dakopatts), rabbit anti-PGP 9.5 (1:2000; gift from Anne Zurn, Lausanne, Switzerland), rabbit anti-mouse Versican V0/V1 (recognizing the GAG $\beta$-domain; 1:2000; Dours-Zimmermann et al., 2009), and Alexa Fluor 488-conjugated IB4 (1:1000; Invitrogen). Secondary antibodies were Alexa Fluor 488-conjugated goat anti-mouse IgG (1:5000), Alexa Fluor 568-conjugated goat anti-mouse IgG $(1: 10,000)$, Pacific Blueconjugated goat anti-mouse IgG (1:1000), Alexa Fluor 633-conjugated goat anti-rat IgG (1:2000), Alexa Fluor 633-conjugated goat anti-guinea pig IgG (1:2000), Alexa Fluor 488-conjugated donkey anti-goat (1:2000), Alexa Fluor 568-conjugated goat anti-chicken IgY (1:10,000), Alexa Fluor 568-conjugated goat anti-rabbit $\operatorname{IgG}(1: 10,000)$, and Alexa Fluor 488-conjugated goat anti-rabbit $\operatorname{IgG}$ (1:2000; all from Invitrogen). To stain nuclei, 1:1000 Hoechst (Invitrogen) was added to the secondary antibody mixture. After washing, sections were imaged using a Leica SP5 confocal microscope or epifluorescence microscope (Axio Imager.M2; Zeiss). Analysis of immunostaining was performed blinded to genotype. Images were processed using EMBL Image ( V $1.45 \mathrm{~h}$, National Institutes of Health) or Corel Photopaint X3 software (v13.0.0.576; Corel) using global adjustments in brightness and contrast. For marker prevalence analysis, at least 1000 neurons were scored from nonadjacent L4 and L5 DRG sections from four to five mice per genotype. To determine the percentage of labeled neurons, labeled and nonlabeled profiles were counted in at least four randomly selected sections (separated by $>50$ $\mu \mathrm{m})$ per DRG from at least four animals. Additionally, the crosssectional soma areas of labeled neurons were measured for at least four randomly selected sections of four animals using MetaVue 5.0r3 software (Universal Imaging).

Epidermal sensory innervation. Quantification of epidermal sensory innervation density was performed as described previously (Lindfors et al., 2006). Labeled nerve fibers in the epidermis of at least 10 randomly chosen confocal micrographs ( $20 \mu \mathrm{m}$ stacks) of four animals per genotype were counted and the fiber density (number of fibers $/ 1000 \mu \mathrm{m}^{2}$ ) was calculated. Imaris software (v6.2 Bitplane AG) was used to reconstruct 3D models of 10 randomly chosen confocal stacks of four animals per genotype. The innervation depth of sensory-free nerve endings was determined by making use of surface rendering of the keratinocyte nuclei to distinguish between the different epidermal layers. Analysis of Merkel cell-neurite complex (MCs) was performed by thorough focusing of Troma-I and NF200 double-stained skin sections using an epifluorescence microscope (Axio Imager.M2; Zeiss). MCs were counted as properly innervated if NF200-positive fibers clearly reach the MC surface as their target. At least 50 randomly chosen MCs of three animals per genotype were used for analysis.

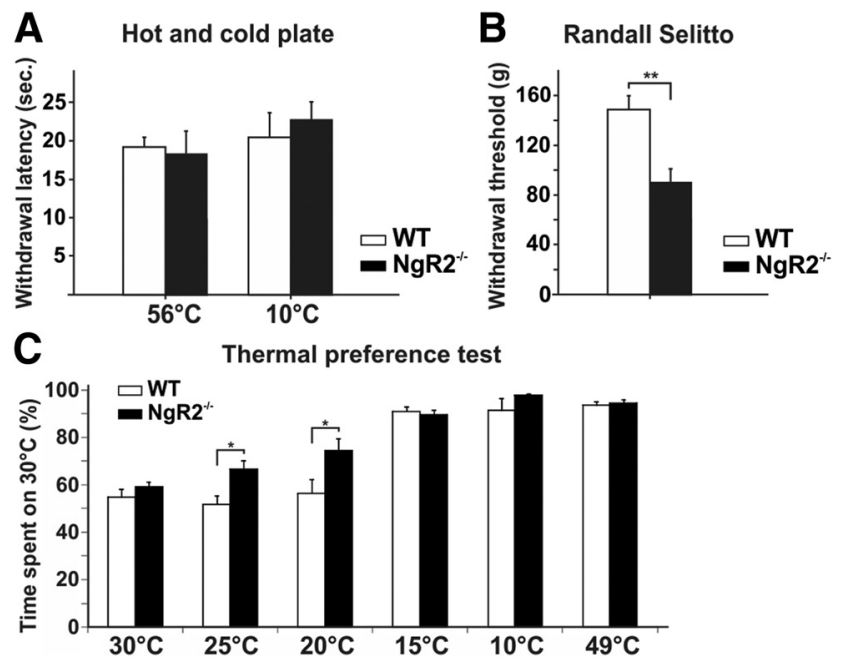

Figure 3. NgR2-deficient mice display sensory deficits for mechanical pain and cold sensation. $\boldsymbol{A}$, Thermal sensitivity measured in WT versus NgR2 knock-out mice, using hot-plate and cold-plate tests. Values represent the latency $(s)$ for animals to lick their hindpaws or jump ( $n=$ 8 per genotype). $\boldsymbol{B}$, Response to mechanical forces. Note that $\mathrm{NgR2}{ }^{-1-}$ mice had lower threshold responses than WT mice ${ }^{* *} p<0.01 ; n=8$ per genotype). $C$, Thermal preference test. The time indicated is the fraction spent by the mice on the $30^{\circ} \mathrm{C}$ plate measured over $5 \mathrm{~min}$. $\mathrm{NgR2} 2^{-1-}$ mice spent significantly less time than WT mice at the 25 and $20^{\circ} \mathrm{C}$ test temperatures $\left({ }^{*} p<0.05 ; n=8\right.$ per genotype). Data are presented as mean \pm SEM.

Neurite outgrowth and stripe assays. Poly-L-lysine $(10 \mu \mathrm{g} / \mathrm{ml})$ glass coverslips were first coated overnight with proteins at indicated concentrations at $4^{\circ} \mathrm{C}$, followed by $5 \mu \mathrm{g} / \mathrm{ml}$ laminin (Sigma-Aldrich) for $2 \mathrm{~h}$ at $37^{\circ} \mathrm{C}$. DRGs from three to five animals (P2) for each genotype were dissociated and cultured as described previously (Schweigreiter et al., 2004). For neurite outgrowth assessment, cells were fixed in $4 \%$ PFA for 10 min, washed in PBS, and incubated at $4^{\circ} \mathrm{C}$ overnight with anti- $\beta$-IIItubulin antibodies (clone TuJ1; 1:1000 in PBS/0.3\% Triton X-100; R\&D Systems). The following day, coverslips were washed and incubated with Alexa Fluor 488- or 594-conjugated goat-anti-mouse antibody (1:2000; Invitrogen). Two to three coverslips were assessed per experiment and $10-12$ images were randomly taken per coverslip, typically resulting in $150-300$ cells/condition. Stripe assays were essentially performed as described previously (Dutt et al., 2011). Proteins together with $1 \mu \mathrm{g} / \mathrm{ml}$ goat anti-Fc-Cy3 (Sigma-Aldrich) or goat anti-mouse-Pacific Blue (Invitrogen) were injected into matrices ( $90 \mu \mathrm{m}$ width) placed on $22 \mathrm{~mm}$ glass coverslips, resulting in red or blue fluorescent stripes. EphrinA4-Fc was used in concentrations of $10 \mu \mathrm{g} / \mathrm{ml}$, Aggrecan at $5 \mu \mathrm{g} / \mathrm{ml}$, Versican V3 at $1 \mu \mathrm{g} / \mathrm{ml}$, and Versican V0 and V1 cell lysates at $100 \mu \mathrm{g} / \mathrm{ml}$. Ephrin-A4-Fc was used after preclustering with anti-humanFc-Cy3 antibody (1:5; Sigma-Aldrich). After incubation for $1 \mathrm{~h}$ at $37^{\circ} \mathrm{C}$, matrices were carefully removed and coverslips washed with PBS. The coverslips were further coated with $5 \mu \mathrm{g} / \mathrm{ml}$ laminin for $1 \mathrm{~h}$ at $37^{\circ} \mathrm{C}$. Dissociated DRG neurons of P2 mice were cultured in the presence of $50 \mathrm{ng} / \mathrm{ml} \mathrm{NGF}$ for $16 \mathrm{~h}$ on the stripe-coated coverslips. After fixation in 1\% PFA in PBS for 5 min followed by $15 \mathrm{~min}$ of methanol at $-20^{\circ} \mathrm{C}$, cells were incubated with mouse anti-NF200 (1:1000) or rabbit anti-PGP 9.5 (1:2000) and Alexa Fluor 488-conjugated IB4 (1:1000). Secondary antibodies were goat antirabbit-Alexa Fluor 568 (1:10,000; Invitrogen), goat anti-mouse-Alexa Fluor 488 (1:5000), and goat anti-mouse-Pacific Blue (1:2000). The percentage of neurons that crossed the stripe border was determined by counting 30-50 individual neurons per experiment. To block the inhibitory effect of Versican V3, stripes were incubated with soluble NgR2$\mathrm{mFc}$ or $\mathrm{mFc}$ at $10 \mu \mathrm{g} / \mathrm{ml}$ for $45 \mathrm{~min}$ at $37^{\circ} \mathrm{C}$. Neurons were visualized with rabbit anti-PGP9.5 and stained with Alexa Fluor 488-conjugated IB4.

Statistical analysis. Statistical tests depended on sample size, distribution, and number of variables. The nonparametric Mann-Whitney $U$ test or the parametric Student's unpaired two-tailed $t$ test were used for comparison between groups, while the Mann-Whitney $U$ test was used for 

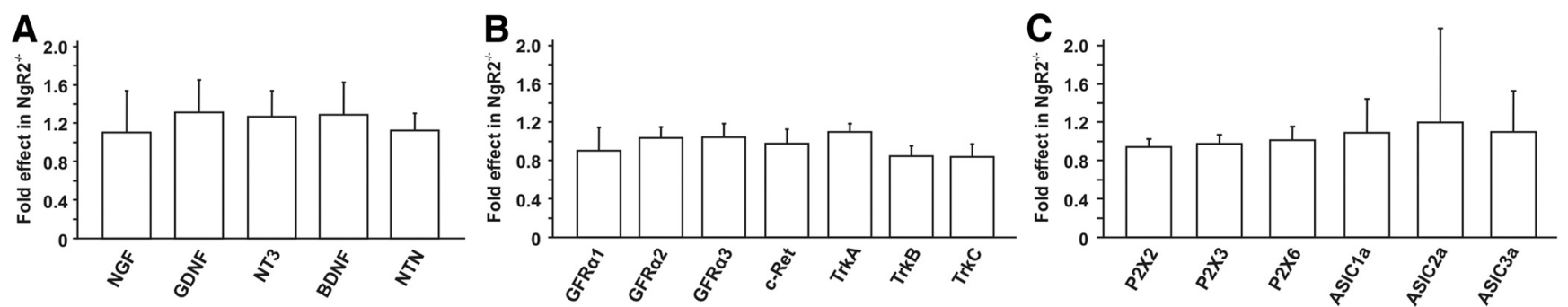

Figure 4. Expression levels of skin-derived growth factors and their cognate receptors in $\mathrm{NgR2}{ }^{-/-}$mice are not altered. $A, q R T-P C R$ revealed no significant differences in expression level of the growth factors NGF, NT3, BDNF, GDNF, and NTN in the skin of NgR2 ${ }^{-1-}$ compared with control animals. B, Growth factor receptors (GFR $\alpha 1$, GFR $\alpha 2$, GFR $\alpha 3$, , c-Ret, TrkA, TrkB, and TrkC) appeared not to be regulated on mRNA level in DRG of NgR2 $-1-$ mice. $(p>0.5, n=4)$. C, Purinergic receptors (P2X2, P2X3, and P2X6) as well as acid sensing channels ASIC1a, ASIC2a, and ASIC3a appeared not to be regulated on $\mathrm{mRNA}$ level in DRG of $\mathrm{NgR2}^{-1-}$ mice. Data are presented as mean $\pm \mathrm{SEM}$ for four animals; samples run in triplicates. Values are normalized to WT expression value.

intra-individual comparisons. All data are expressed as mean \pm SEM. A value of $p<0.05$ was considered significant.

\section{Results \\ $\mathrm{NgR} 2$ is expressed by DRG neurons of different subpopulations}

Adult sensory neurons have previously been reported to express NgR2 (Laurén et al., 2003; Venkatesh et al., 2005), although a detailed expression pattern has not been evaluated. Immunohistochemical studies of NgR2 have been compromised by the lack of specific antibodies; all are commercially available antisera to $\mathrm{NgR} 2$ stain knock-out tissue. We therefore used ISH with DIGlabeled cRNA probes to NgR2 and found that $\sim 80 \%$ (79 \pm $1.36 \%, n=3$ ) of all mouse L4/5 DRG neurons express NgR2 mRNA at varying levels (Fig. $1 A$ ). The in situ probes were transcript specific as no signals were seen in tissue from NgR2 knockout mice (Fig. 1A). The size distribution of NgR2-positive neuronal profiles suggests that NgR2 mRNA is mainly expressed by small and large diameter neurons, whereas the NgR2-negative neurons are predominantly medium sized (Fig. $1 B$ ). To relate the expression of $\mathrm{NgR} 2$ to functional DRG neuron subtypes we combined ISH with IHC (Fig. 1C) using the markers NF200 (mechanoreceptors and proprioceptors with large axon diameters), IB4 (nonpeptidergic nociceptors), CGRP (peptidergic nociceptors), and TRPV1 (heat-sensitive nociceptors): $48.36 \pm 2.96 \%$ of the NgR2 mRNA-expressing DRG neurons stained for NF200, $40.1 \pm 2.34 \%$ bound IB4, $29.53 \pm 0.59 \%$ contained CGRP, and $16.65 \pm 0.33 \%$ coexpressed TrpV1. Conversely, the vast majority of IB4-binding neurons $(87.03 \pm 1.44 \%)$ and over $50 \%$ of the $\mathrm{CGRP}^{+}(57.72 \pm 3.43 \%)$ or TrpV1 ${ }^{+}$neurons $(56.56 \pm 1.89 \%)$ coexpressed NgR2 mRNA. Almost all NF200 ${ }^{+}$neurons coexpressed NgR2 $(94.21 \pm 2.3 \%)$. The results are in line with the shift of NgR2-negative cells to neurons of medium-sized diameter. No change in the total number of L4/5 DRG neurons (WT, $\left.3821 \pm 66 ; \mathrm{NgR}^{-1-}, 3763 \pm 54 ; p>0.05 ; n=4\right)$, nor in the relative percentage of sensory neuron subsets was observed between genotypes (Fig. 1D,E). Consistently, the size frequency distributions of different neuronal cell body diameters, characteristic of different DRG neuronal subpopulations, were comparable between $\mathrm{NgR}^{-I-}$ and WT mice (Fig. $1 F$ ). There were no obvious differences in the morphology and number of sensory afferent axons in sections of the sciatic nerve (Fig. $1 G$ ). In summary, the results show that $\mathrm{NgR} 2$ is expressed in all sensory subclasses at various levels, preferentially by small-diameter IB4 ${ }^{+}$nociceptive and large mechanosensory neurons, but has no apparent effect on neuronal number and/or differentiation.

\section{NgR2 deficiency increases peripheral but not central afferent} density of nonpeptidergic nociceptors

Because NgR1 is best known for its functions as a suppressor of anatomic plasticity, we investigated whether NgR2 deletion changes the peripheral or central projections of sensory neurons. We compared the peripheral innervation pattern of nociceptive C-fiber terminals in the glabrous skin of WT and $\mathrm{NgR} 2^{-/-}$mice using the pan-neuronal marker TuJ1 ( $\beta$-tubulin III). Fiber density and labeling intensity of the subepidermal nerve plexus in the footpad dermis appeared similar for all genotypes (Fig. 2A). In contrast, quantitative measurements of the total number of $\mathrm{TuJ}^{+}$fibers in the epidermis showed a 1.5 -fold increase of free nerve endings in NgR2 $2^{-1-}$ mice relative to WT animals. (Fig. $2 B$; $3.59 \pm 0.18$ nerve endings per $1000 \mu \mathrm{m}^{2}$ skin for $\mathrm{NgR}^{-1-}$ and $2.50 \pm 0.25$ nerve endings in the control mice; $p<0.01, n=5$ ). Interestingly, this phenotype was not observed in $\mathrm{NgR}^{-1-}$ mice (Fig. $2 A, B$ ), pointing to a specific role for NgR2 in cutaneous sensory innervation. Moreover, no $\mathrm{NF}^{2} 00^{+}$(Fig. 2C) or $\mathrm{TH}^{+}$ fibers (data not shown) were observed that innervated the epidermis in $\mathrm{NgR} 2^{-/-}$animals, excluding the possibility of aberrant sprouting of myelinated proprioceptive or sympathetic fibers, respectively. In addition, afferent innervation of morphologically distinct mechanoreceptors in the footpad was largely unaffected. As shown in Figure $2 \mathrm{C}, \mathrm{NF} 200^{+}$nerve endings were frequently associated with $\mathrm{S} 100$-positive cells to form structures morphologically reminiscent of Meissner's corpuscles or with MCs stained with Troma-I (Fig. 2C). Localization of MCs at the basal layer of the epidermis, their number, and percentage of innervated Troma-I-positive cells appeared to be unaltered $(89.64 \pm 2.01 \%$ of Troma-I-positive cells was innervated in NgR2 ${ }^{-1-}$ mice, $88.17 \pm 0.4 \%$ in control animals, $n=3, p>$ $0.01)$.

Mice lacking axonal NgR2 ${ }^{-1-}$ showed no visible difference in the labeling of nociceptive fibers by CGRP or IB4 in the lumbosacral spinal cord, suggesting that the central projections of nonpeptidergic neurons are not affected. Both the staining intensity and the afferent distribution were indistinguishable from controls (Fig. 2D). We performed double labeling of CGRP and TuJ1 in the footpad and compared the density of $\mathrm{CGRP}^{+}$fibers in $\mathrm{NgR} 2^{-/-}$and WT control mice at P5 (Fig. 2E), when epidermal density of CGRP ${ }^{+}$fibers peaks during development (Peters et al., 2002). As in adult animals, total fiber density was significantly increased in $\mathrm{NgR} 2^{-1-}$ mice (Fig. $2 F ; 8.43 \pm 0.30$ nerve endings per $1000 \mu \mathrm{m}^{2}$ skin for $\mathrm{NgR} 2^{-/-}$and $7.20 \pm 0.21$ nerve endings in the control mice; $p<0.01, n=4$ ), whereas the peptidergic C-fiber population was unaffected (Fig. $2 F ; 2.32 \pm 0.21$ nerve endings per $1000 \mu \mathrm{m}^{2}$ skin for NgR2 ${ }^{-1-}$ and $2.44 \pm 0.32$ nerve 

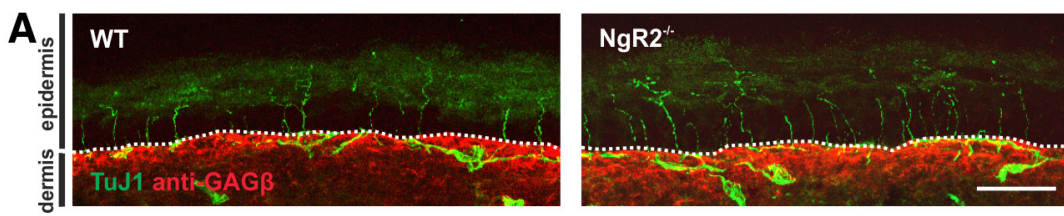

B

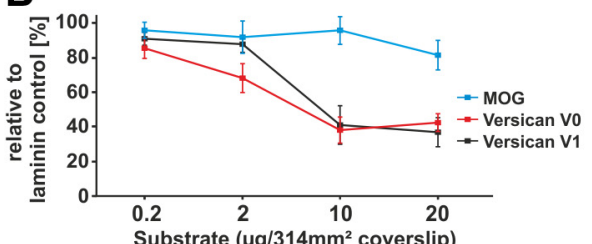

C

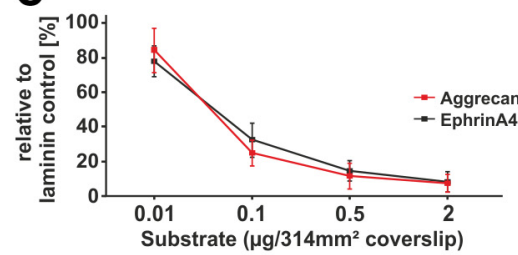

D
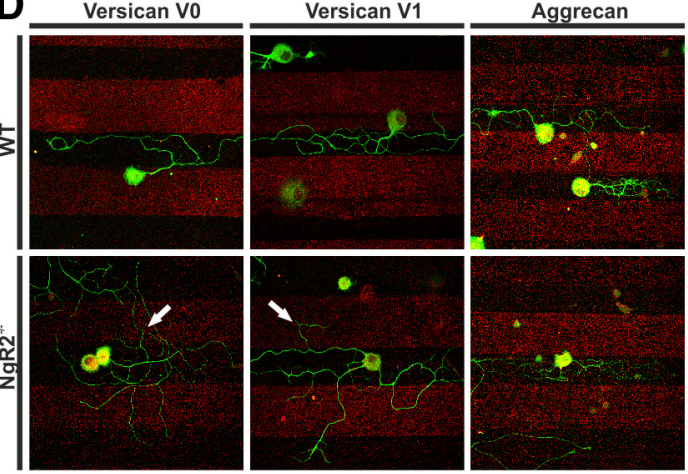

EphrinA4
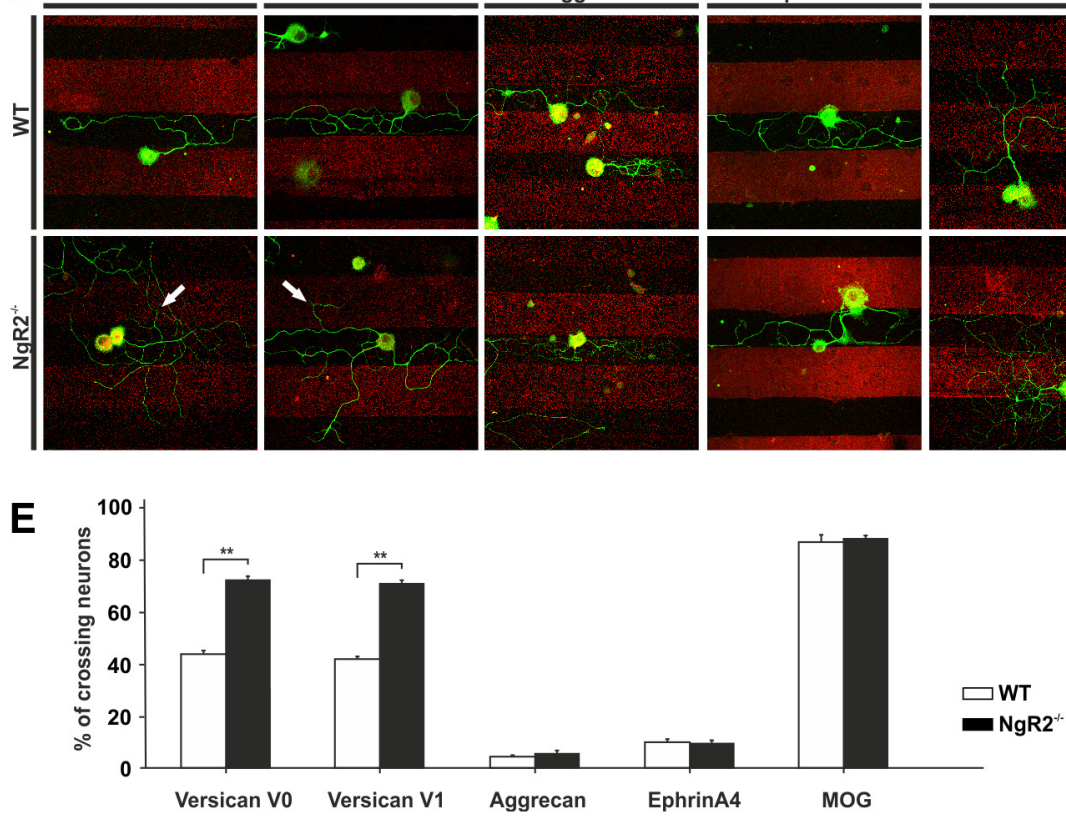

Figure 5. Versican repels NgR2-expressing DRG neurons. $\boldsymbol{A}$, Confocal micrographs of cross sections of the glabrous hindpaw skin of NgR2 $2^{-1-}$ and WT mice stained with TuJ1 (green) and anti-GAG $\beta$ specific for VersicanV0/V1 (red). Expression and distribution of VersicanV0/V1 was unaltered in NgR2 ${ }^{-1-}$ mice. $\boldsymbol{B}, \boldsymbol{C}$, Dose-dependent inhibition of WT DRG neurite outgrowth on indicated substrates from $(\boldsymbol{B})$ cell lysates and $(\boldsymbol{C})$ purified proteins. $\boldsymbol{D}, \mathrm{NgR} 2$ is required for Versican repulsive activity. Dissociated DRG neurons of NgR2 $2^{-1-}$ and control P2 mice were grown on alternating stripes coated with laminin ( $L$; black) and the indicated substrates ( $S$ red). Neurons were stained with TuJ1 (green) to visualize axons. Arrows indicate branch points on inhibitory substrate stripes. $\boldsymbol{E}$, Quantification of neurons crossing the inhibitory border. $\mathrm{NgR2} 2^{-1-}$ neurons were less repelled by Versican V0 or V1. Aggrecan and Ephrin-A4-Fc were strongly repulsive for DRG neurons of both genotypes $\left({ }^{* *} p<0.01, n=3\right)$. Scale bars: $A, D, 40 \mu \mathrm{m}$.

endings in the control mice; $p>0.5, n=4)$. This indicates that nonpeptidergic nociceptive fibers may account for the increased innervation density. Because IB4-lectin binds strongly to keratinocytes, a direct identification of the nonpeptidergic fibers in the epidermis is difficult. However, epidermal innervation is spatially segregated, with nonpeptidergic, $\mathrm{MrgD}^{+}$nociceptors terminating predominantly in the stratum granulosum, and $\mathrm{CGRP}^{+} \mathrm{fi}^{-}$ bers in the underlying stratum spinosum (Zylka et al., 2005). High-resolution confocal microscopy and 3D reconstructions of $\mathrm{TuJ} 1^{+}$fibers (Fig. $2 G$ ) revealed significantly more TuJ $1^{+}$fibers innervating the stratum granulosum in $\mathrm{NgR} 2^{-1-}$ mice than in WT controls (Fig. $2 H ; 8.05 \pm 0.31$ nerve endings per confocal stack for $\mathrm{NgR}^{-1-}$ vs $5.93 \pm 0.68$ nerve endings in the control mice; $p<0.05, p<0.05, n=4$ ), while the number of fibers terminating in the stratum spinosum was unaffected (Fig. $2 \mathrm{H}$; $2.53 \pm 0.22$ nerve endings per confocal stack for $\mathrm{NgR} 2^{-1-}$ and $2.80 \pm 0.30$ nerve endings in the control mice; $p>0.05, n=4$ ).

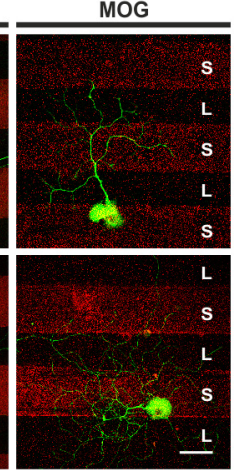

Moreover, $\mathrm{TuJ}^{+}$nerve endings terminating in the stratum granulosum appeared to be $\mathrm{P} 2 \mathrm{X} 3$ positive, consistent with the notion that they are nonpeptidergic (Fig. 2G)

Hence, NgR2 is essential for cutaneous peripheral projection of nonpeptidergic nociceptive neurons both in young and mature adult mice, but is dispensable for the integrity of their central projections.

\section{Loss of NgR2 enhances sensitivity to mechanical stimuli and impairs cold sensitivity}

As an initial means to explore whether absence of NgR2 and the resulting sensory hyperinnervation is accompanied by alterations in nociception, we examined the behavioral responses of $\mathrm{NgR} 2^{-/-}$mice to noxious thermal and mechanical stimuli. Acute thermal heat pain sensation was tested using the hot-plate test. The mean latency of withdrawal of hindpaw followed by licking or biting at $55.5-56^{\circ} \mathrm{C}$ was $18.13 \pm 3.06 \mathrm{~s}$ for $\mathrm{NgR}^{-1-}$ and $19.09 \pm 1.33 \mathrm{~s}$ for $\mathrm{NgR}^{+/+}$littermate controls (Fig. 3A). The difference between groups in this heat thermal test was insignificant $(p>0.05 ; n=8)$. In contrast, there was a clear difference in sensitivity to noxious mechanical pressure. The mean weight that resulted in a hindpaw withdrawal in the Randall-Selitto test was $148.67 \pm 11.59 \mathrm{~g}$ for $\mathrm{NgR} 2^{+/+}$mice and $89.74 \pm 11.25 \mathrm{~g}$ for $\mathrm{NgR}^{-1-}$ littermate controls (Fig. $3 B ; p<0.01 ; n=8$ ). This phenotype could not be ascribed to locomotory defects as tested by an accelerating rotarod (data not shown), so we hypothesized that $\mathrm{NgR} 2$ receptors on peripheral terminals contribute to the mechanosensitive phenotype. As hypersensitivity to mechanical forces often correlates with altered behavioral cold sensitivity (da Costa et al., 2010), we tested for behavioral differences in response to cold. NgR2 ${ }^{-1-}$ and littermate control mice responded to the cold-plate test with similar paw withdrawal latencies (Fig. $3 A ; p>0.05 ; n=8$ ). However, a temperature preference assay revealed distinct differences between genotypes in their ability to discriminate between warm and cold surfaces. Mice were allowed to explore two adjacent plates, with one held at $30^{\circ} \mathrm{C}$ and the other set at temperatures ranging from 30 to $10^{\circ} \mathrm{C}$. The percentage of time spent on the $30^{\circ} \mathrm{C}$ surface was measured over a $5 \mathrm{~min}$ period. When placed on equal temperatures (both $30^{\circ} \mathrm{C}$ ), neither WT nor mutant mice displayed a preference, i.e., they spent $\sim 50 \%$ of the time on each side (Fig. $3 C ; p>0.05, n=8$ ). In contrast, when selecting between $30^{\circ} \mathrm{C}$ and $25^{\circ} \mathrm{C}$ or $30^{\circ} \mathrm{C}$ and $20^{\circ} \mathrm{C}, \mathrm{NgR} 2^{-1-}$ mice exhibited a significantly stronger avoidance for cooler (or preference for warmer) temperatures than their WT littermates (Fig. $3 C$; $p<$ $0.05, n=8$ ). There appeared to be discrimination between noxious cold temperatures $\left(15^{\circ} \mathrm{C}\right.$ and lower) and $30^{\circ} \mathrm{C}$ as all mice, independent of their genotype spent $>90 \%$ of the time on the 
$30^{\circ} \mathrm{C}$ plate (Fig. $3 C ; p>0.05 ; n=8$ ). When the test plate was set to a temperature of $49^{\circ} \mathrm{C}$, both $\mathrm{NgR} 2^{-1-}$ and WT littermates showed a robust avoidance (Fig. $3 C)$ of the hot side. Thus, whereas $\mathrm{NgR} 2^{-1-}$ mice exhibit significant deficits in cold sensing in the range between 25 and $20^{\circ} \mathrm{C}$, they retain a normal response to noxious cold temperatures and a significant capacity for heat avoidance.

\section{NgR2 does not affect the expression of skin-derived growth factors, their cognate receptors, or mechanosensors} Signaling by GDNF is important for the epidermal innervation of nonpeptidergic fibers (Zwick et al., 2002). Chronic as well as acute intradermal GDNF administration is associated with lower mechanical thresholds in cutaneous nociceptors with no effect on the thermal behavior of the same neurons (Albers et al., 2006; Bogen et al., 2008). Furthermore, overexpression of NTN in the skin led to an increased sensitivity to cool temperatures (Wang et al., 2013). We thus analyzed whether the expression of skin-derived growth factors and/or their receptors on DRG neurons was altered in $\mathrm{NgR} 2^{-1-}$ mice. Comparative analysis of transcripts encoding GDNF, BDNF, NGF, NT3, and NTN in the skin of $\mathrm{NgR} 2^{-/-}$and control mice showed no significant difference. Likewise, the relative mRNA levels of GFR $\alpha 1 / 2 / 3$, c-Ret, TrkA, TrkB, and TrkC were similar in $\mathrm{WT}$ and $\mathrm{NgR} 2^{-1-}$ mice (Fig. $4 A, B$ ). Thus, the hypertrophy of terminal projections in the glabrous footpad skin of $\mathrm{NgR} 2^{-/-}$mice does not correlate with levels of skin-derived neurotrophic factors.

Changes in the mechanosensitivity of primary afferents could in principle be a consequence of altered transcription levels of potential mechanosensitive ion channels or receptors. Purinergic receptors of the P2X family ( $\mathrm{Xu}$ et al., 2008; Banerjee et al., 2009; Hsieh et al., 2012), and acidsensing ion channels (ASICs) are expressed in sensory neurons of the DRG and were suggested to be involved in mechanical pain perception (Price et al., 2000, 2001). For nociception Asic2a and Asic3a are of particular interest as both are expressed by smalldiameter DRG neurons (García-Añoveros et al., 2001; Duggan et al., 2002). No difference in the expression of P2X3, P2X2, and $\mathrm{P} 2 \mathrm{X} 6$ was detected in NgR2 ${ }^{-1-}$ DRGs (Fig. 4C), consistent with our data that NgR2 knock-out does not alter the ratio of P2X3positive DRG neurons to other subtypes (Fig. $1 D, E$ ). Like for P2X channels, no alterations in DRG expression of Asicla, Asic2a, or Asic3a were found, suggesting that deficits in the mechanosensitivity of $\mathrm{NgR} 2^{-/-}$mice are not due to changes in channels that potentially mediate mechanosensation. In addition, loss of NgR2 did not affect the number of neurons that express TrpM8, a cold temperature-sensitive receptor (data not shown; Bautista et al., 2007; Colburn et al., 2007).
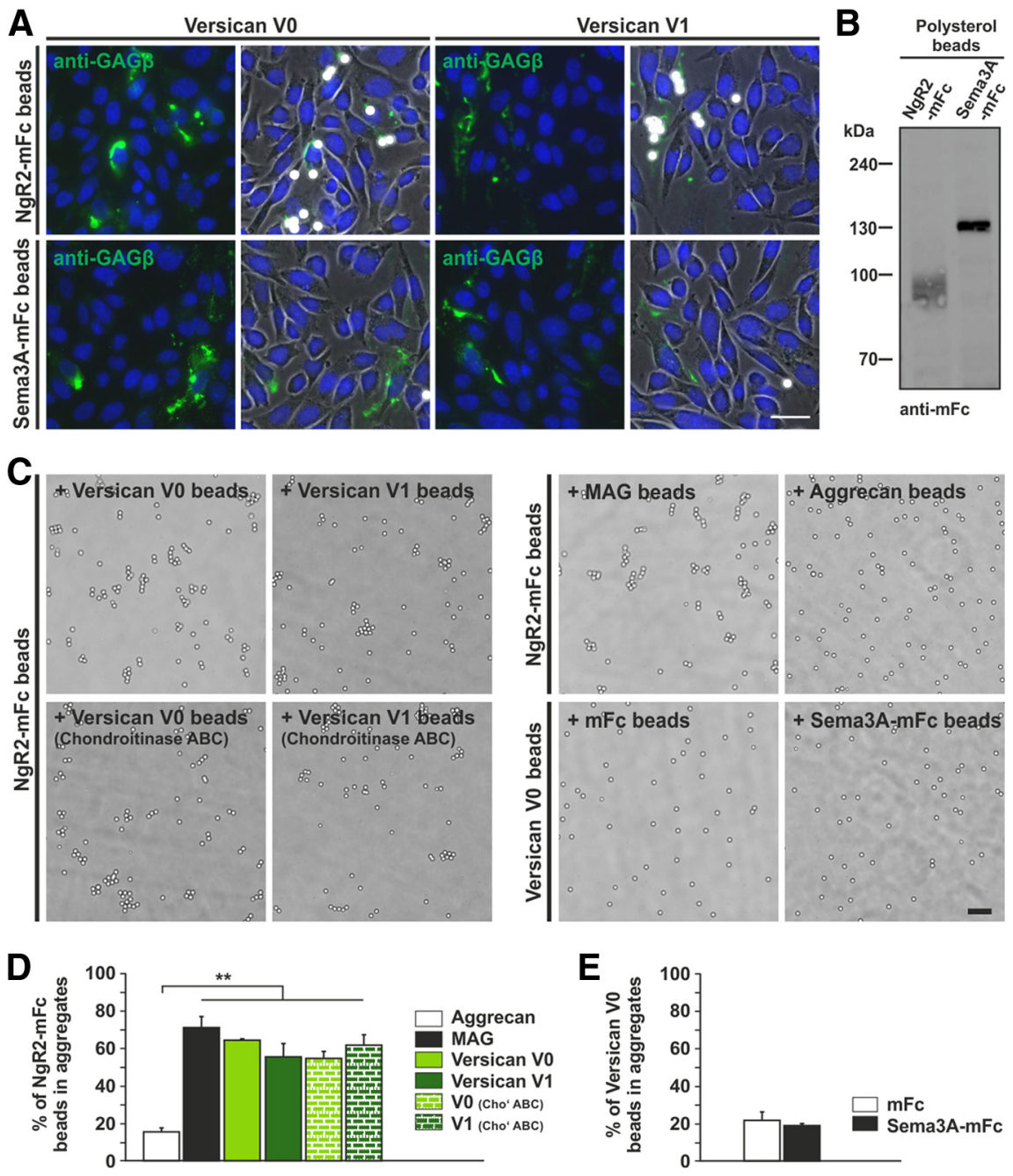

Figure 6. $\mathrm{NgR2-mFc}$ binds specifically to Versican V0/V1. $\boldsymbol{A}$, Versican V0 or V1-expressing $\mathrm{CHO}$ cells were incubated with $\mathrm{NgR2}$-mFc or Sema3A-mFc immobilized on polystyrol beads. Expression of Versican isoforms was visualized with anti-GAG $\beta$ antibodies (green). Nuclei were stained with Hoechst (blue). Note that only NgR2-mFc beads bound to Versican-expressing $\mathrm{CHO}$

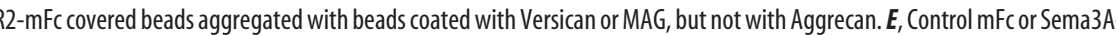
$\mathrm{mF}$ c beads remained largely monomeric. Scale bars: $A, C, 40 \mu \mathrm{m}$.

\section{$\mathrm{NgR} 2$ is required to mediate sensitivity to Versican V0/V1}

It is tempting to propose that $\mathrm{NgR} 2$ signaling at nerve terminals affects the ability of nonpeptidergic neurons to respond to factors in the skin that either promote or inhibit axon extension and branching. To test this idea, we used an in vitro boundary assay in which DRG axons had to encounter stripes of different keratinocyte-derived proteins. We focused on two chondroitin sulfate proteoglycans, Versican and Aggrecan, and on Ephrin4A, as these proteins are expressed in the skin throughout development (Zimmermann et al., 1994; Moss et al., 2005; Malgouries et al., 2008). Notably, two isoforms of Versican, V0 and V1, are expressed by keratinocytes and fibroblasts in the proliferating zone of the epidermis and are released to the extracellular matrix at the DEJ (Zimmermann et al., 1994). Neither expression nor localization of Versican V0/V1 was noticeably altered at the DEJ of NgR2 ${ }^{-1-}$ mice (Fig. $5 A$ ). All substrate molecules tested significantly inhibited neurite outgrowth of WT DRG neurons in a concentration-dependent manner (Fig. $5 B, C$ ) as previously re- 
ported (Borisoff et al., 2003; Moss et al., 2005; Dutt et al., 2011). When perinatal WT DRG neurons were grown in the presence of NGF to select for nociceptive neurons, on alternating lanes of laminin and Versican (Fig. 5D), almost $60 \%$ of the dissociated neurons grew preferentially on the permissive laminin lanes but failed to extend neurites past the border of Versican V0 or Versican V1-enriched stripes (Fig. 5D,E). In contrast, neurites were able to cross unimpeded onto lanes enriched in MOG (Fig. $5 D, E)$. Interestingly, the proportion of $\mathrm{NgR} 2^{-1-}$ DRG neurons with neurites that crossed the border onto the Versican V0 or V1 substrates was $>30 \%$ higher than that of WT neurons (Fig. $5 D, E$; $72.41 \pm 3.36 \% \mathrm{NgR}^{-1-}$ neurons cross onto Versican V0 and $71.03 \pm 2.41 \%$ onto Versican V1 vs $44.04 \pm 1.44 \%$ of WT neurons crossing onto Versican V0 and $42.1 \pm 1.32 \%$ onto Versican $\mathrm{V} 1, n=3, p<0.01)$. No difference in crossing frequency was observed between WT and knock-out neurons at the laminin/ Aggrecan or laminin/EphrinA4-Fc border (Fig. 5D,E). There was also an increase in the incidence of crossed fibers forming collateral branches on the Versican lanes $(1.00 \pm 0.27$ branch points per neurite on V0 for $\mathrm{NgR} 2^{-1-}$ neurons vs $0.34 \pm 0.10$ branch points per neurite for WT neurons; $p<0.05, n=4)$. This effect was not observed at the laminin/Ephrin-A4 border. As deletion of $\mathrm{NgR} 2$ significantly attenuated Versican-induced repulsion of DRG neurons, we concluded that NgR2 is required for Versican inhibitory activity.

\section{In vitro binding of $\mathrm{NgR2}-\mathrm{mFc}$ to Versican isoforms}

To investigate whether the ectodomain of NgR2 interacts with Versican V0 or V1, NgR2-mFc fusion proteins bound to polystyrol beads were tested for the ability to bind to $\mathrm{CHO}$ cells expressing untagged recombinant Versican V0 or V1 proteins (Fig. 6A). Staining with anti-GAG $\beta$ antibodies verified that the Versican isoforms are expressed and secreted by the transfected cells. NgR2 beads specifically bound to Versican isoform-expressing $\mathrm{CHO}$ cells but not to control cells. Beads covered with equivalent levels of Sema3A-mFc (Fig. 6B) served as controls (Fig. 6A). To examine the interaction of $\mathrm{NgR} 2$ and Versican $\mathrm{V} 0$ or $\mathrm{V} 1$ in a cell-free experiment, we used a bead aggregation assay (Fig. 6C). NgR2$\mathrm{mFc}$ beads were incubated with beads coated with purified recombinant Versican V0 or V1proteins. Negative controls included beads with mFc-tag or Sema3A-mFc and beads coated with purified Aggrecan. MAG-coated beads were used as a positive control. NgR2-mFc beads were largely monomeric ( $90.36 \pm$ $2.13 \%)$ at the start of the incubation period. Bead aggregation was monitored after a $45 \mathrm{~min}$ incubation period. NgR2-mFc was found to promote aggregates consisting of two or more beads when incubated with Versican V0 or V1 (Fig. 6D; 64.52 $\pm 0.66 \%$ of beads in aggregates for Versican V0; $55.92 \pm 7.12 \%$ for Versican V1; $n=3$ ). Similar aggregation properties were found between NgR2 and its known high-affinity binding partner MAG (Fig. 6D; $71.34 \pm 5.71 \% ; n=3$ ), whereas Aggrecan (Fig. $6 D$; $15.73 \pm 2.03 \%), \mathrm{mFc}$-tag, or beads loaded with Sema3A-mFc (Fig. $6 E ; 21.58 \pm 2.51 \%$ and $18.83 \pm 0.7 \%$ ) did not aggregate, highlighting the specificity of NgR2 binding for Versican (Fig. $6 D, E)$. Prior digestion of Versican beads with Chondroitinase $\mathrm{ABC}$ did not significantly affect bead aggregation (Fig. 6C,D; $54.9 \pm 3.84 \%$ of beads in aggregates for digested VersicanV0 and $61.95 \pm 5.62 \%$ for VersicanV1; $n=3$ ), suggesting that NgR2 binding does not depend on GAG side chains of the Versican isoforms. Although the results do not exclude a possible contribution of residual GAG stubs in the NgR2/Versican interaction, our data are in line with recent biochemical findings demonstrating that $\mathrm{NgR} 2$, in contrast to its homologs $\mathrm{NgR} 1$ and $\mathrm{NgR} 3$, does
A
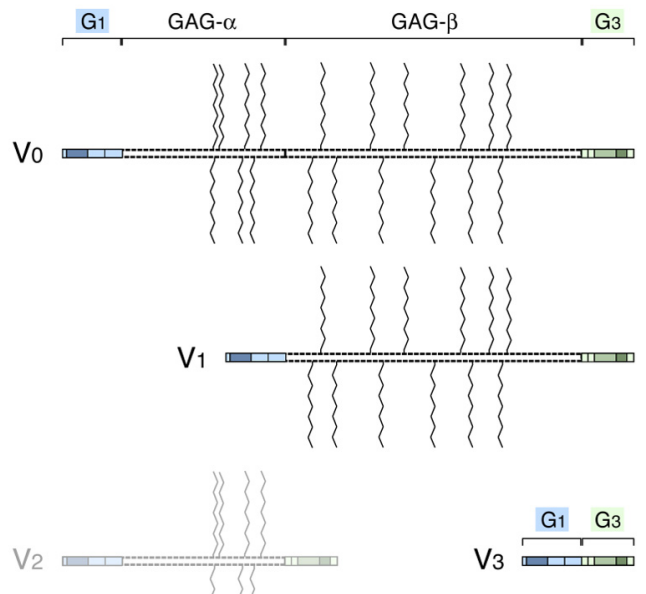

B NgR2-mFc beads Sema3A-mFc beads
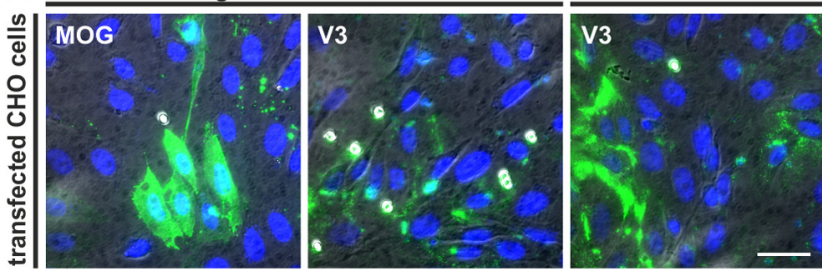

Figure 7. $\mathrm{NgR2}$-mFc binds to the shortest Versican isoform, Versican V3. $\boldsymbol{A}$, Structural model of Versican isoforms used for in vitro experiments. The longest version, Versican V0, consists of the G1, GAG- $\alpha, \mathrm{GAG}-\beta$, and $\mathrm{G} 3$ domains. Versican V1 lacks the GAG- $\alpha$ domain. Versican V 3 has no GAG attachment site and thus consists only of the $\mathrm{G} 1$ and $\mathrm{G} 3$ domains. $\boldsymbol{B}$, Binding of NgR2$\mathrm{mFc}$ or Sema3A-mFc beads to CHO cells expressing Versican V3 or MOG. Versican V3 was visualized with anti-myc (green), MOG with anti-MOG antibodies (green). Nuclei were stained with Hoechst (blue). Scale bar, $40 \mu \mathrm{m}$.

not associate specifically with GAG chains (Dickendesher et al., 2012). Instead, $\mathrm{NgR} 2$ probably interacts with the protein core of Versican isoforms.

\section{NgR2 binds to the C-terminal G3 domain of Versican}

To address this point in more detail, we performed NgR2-Fc binding assays to Versican V3. Versican V3 is the shortest Versican splice variant, consisting of the N-terminal G1 and C-terminal G3 domains, shared by all Versican isoforms, but lacking the domain for GAG chain modification (Fig. 7A). In the cell-based binding assay, NgR2-mFc beads bound effectively to Versican V3-transfected cells, but not to MOG-transfected cells. Moreover, no binding of Sema3A-mFc beads to V3-expressing $\mathrm{CHO}$ cells was observed, supporting the specificity of the NgR2-V3 interaction (Fig. $7 B$ ). We also noted that the neurite extension of WT DRG neurons was strongly repelled in a dosedependent manner by Versican V3 substratum (Fig. 8A). In the border assay, at $1 \mu \mathrm{g} / \mathrm{ml}$ Versican $\mathrm{V} 3$, the repulsive effect was significantly more pronounced for nonpeptidergic IB4 ${ }^{+}$neurons than for IB4 ${ }^{-} / \mathrm{NF} 00^{-}$(presumably peptidergic) neurons (Fig. $8 B, C ; 50.09 \pm 4.1 \% \mathrm{IB}^{+}{ }^{+}$neurons were repelled compared with $28.69 \pm 0.96 \% \mathrm{IB}^{-} / \mathrm{NF}^{-} 200^{-}$neurons; $p<0.05 ; n=3$ ), while large $\mathrm{NF}_{200}{ }^{+}$neurons appeared to be unaffected (Fig. $8 B, C$ ). Remarkably, Versican V3 had no significant effect on NgR2 ${ }^{-1-}$ neurons: neurites of both IB4 ${ }^{+}$and IB4 ${ }^{-}$cells freely crossed onto Versican V3-coated stripes (Fig. 8B, C; $93.44 \pm 1.04 \% \mathrm{IB}^{+}{ }^{+}$and $94.05 \pm 1.75 \% \mathrm{IB}^{-}{ }^{-} \mathrm{NNF} 200^{-}$neurons crossed; $p<0.01 ; n=3$ ), suggesting that $\mathrm{NgR} 2$ is necessary for repulsion by Versican V3. Importantly, Versican V3 activity could be abolished by pre- 
A
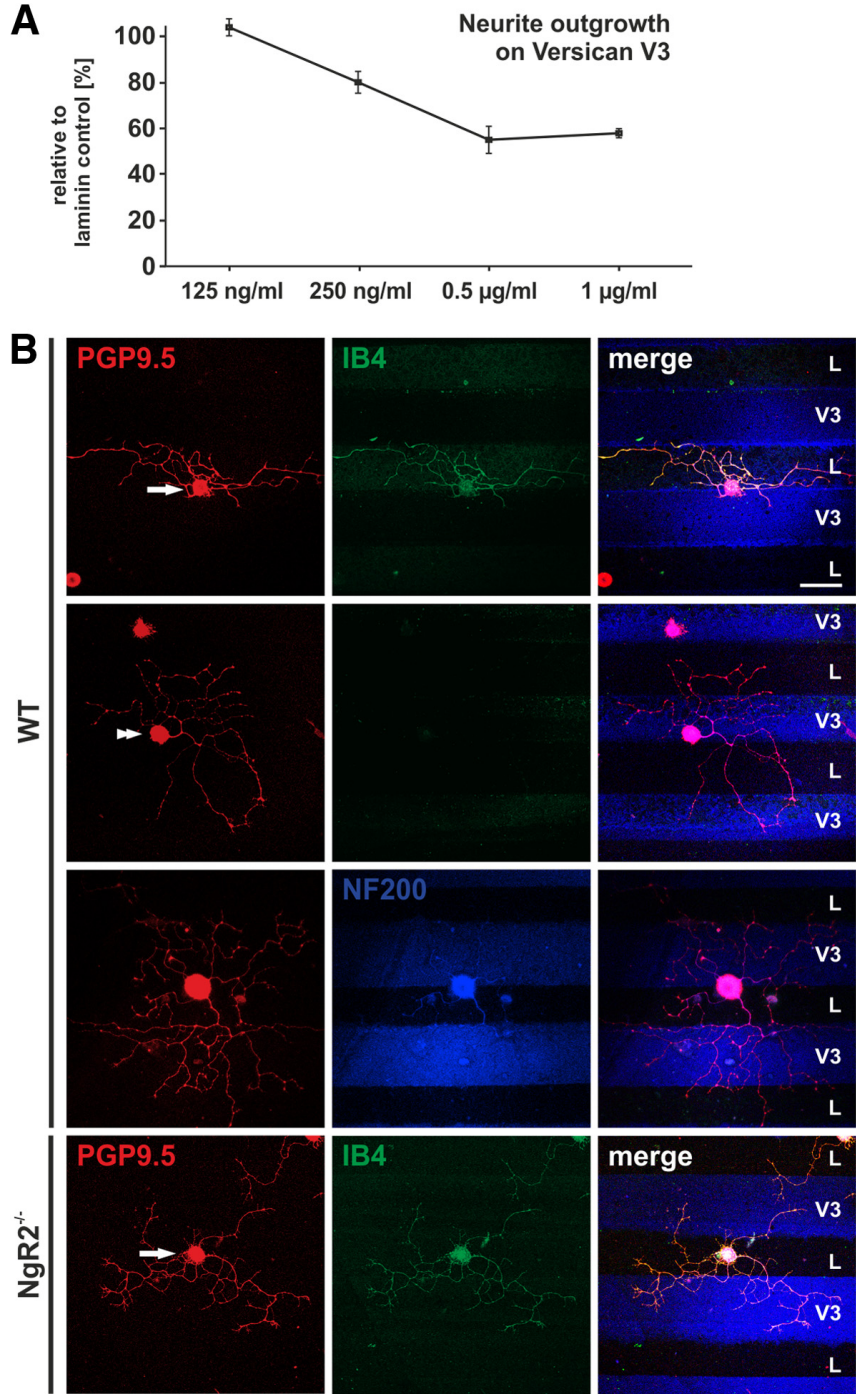

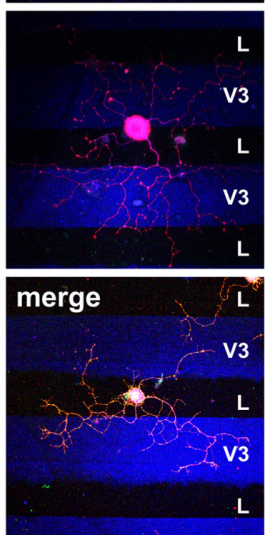

C
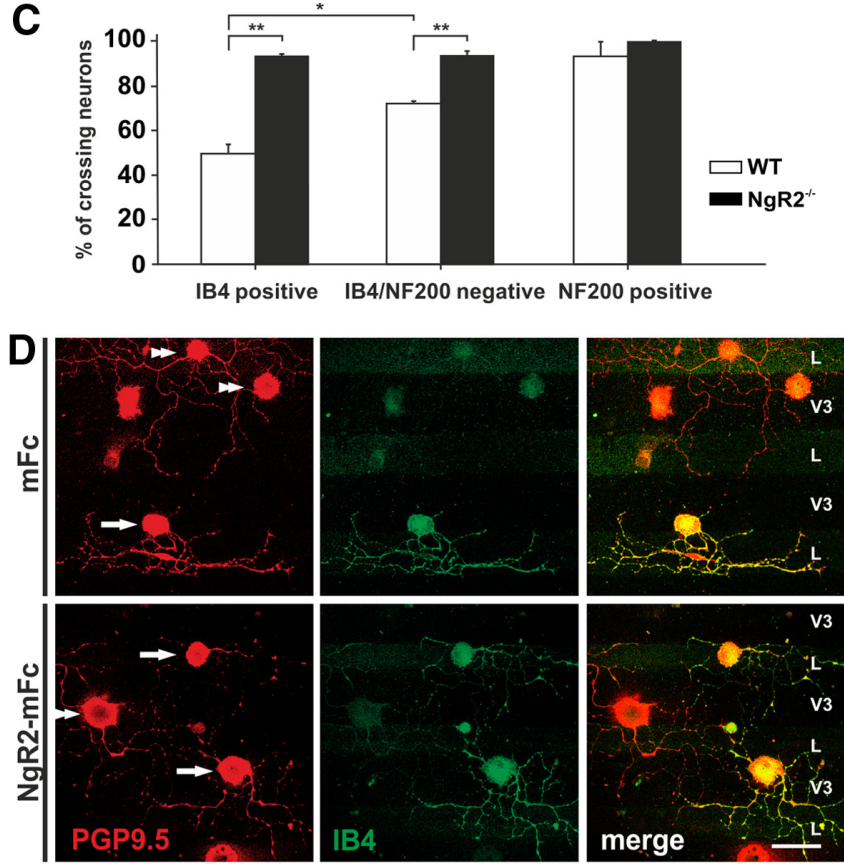

E

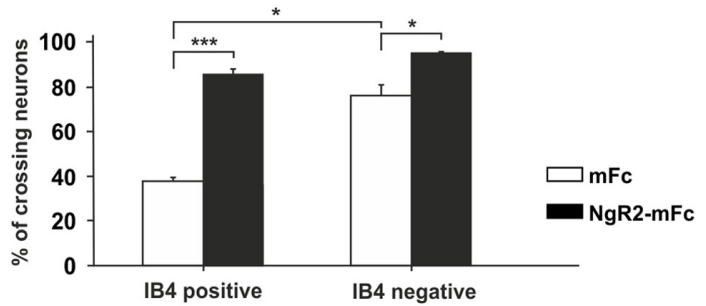

Figure 8. Versican V3 repels NgR2-expressing DRG neurons. A, Dose-dependent outgrowth inhibition of WT DRG neurons by Versican V3 substrate. B, Dissociated DRG neurons of P2 NgR2 ${ }^{-1-}$ and WT mice were grown on stripes coated alternately with Laminin (L; black) and Versican V3 (blue). Neurons were triple stained with the pan-axonal marker PGP9.5 (red), anti-NF200 (blue), and IB4 (green). Arrows indicate IB4 ${ }^{+}$and arrowheads IB4 ${ }^{-}$neurons. Note that NgR2 ${ }^{-1-}$ neurons were not repelled by Versican V3 stripes. C, Quantification shows that the percentage of IB4 ${ }^{+}$WT neurons repelled by Versican V3 was significantly higher than that of IB4 ${ }^{-}$neurons. Note that NgR2 ${ }^{-1-}$ neurons lost their sensitivity to Versican V3 $\left({ }^{*} p<0.05,{ }^{* *} p<0.01 ; n=3\right)$. D, Dissociated DRG neurons of WT P2 mice were grown on alternating stripes coated with purified Versican V3 in the presence of soluble NgR2-mFc or mFc control. Neurons were stained with PGP9.5 (red) and IB4 (green). Arrows indicate IB4 ${ }^{+}$and arrowheads IB4 ${ }^{-}$neurons. $E$, Quantitative analysis shows that the percentage of IB4-binding neurons repelled by Versican V 3 was remarkably reduced upon blocking with $\mathrm{NgR2}$ - $\mathrm{mFc}$, but was not affected upon addition of $\mathrm{mFc}-$ only $\left({ }^{*} p<0.05,{ }^{* * *} p<0.001, n=3\right)$. Scale bars: B, $\boldsymbol{D}, 40 \mu \mathrm{m}$.

incubation with soluble $\mathrm{NgR} 2-\mathrm{mFc}$ but not with control $\mathrm{mFc}$ (Fig. 8 D, E; $85.55 \pm 2.16 \%$ of IB4 ${ }^{+}$neurons and $95.42 \pm 0.24 \%$ of IB4 ${ }^{-}$neurons grew over the Versican V3-coated stripes; $p<$ $0.001, p<0.05 ; n=3$ ), strongly suggesting that growth repulsion was mediated by NgR2. To map the NgR2 binding domain in V3, $\mathrm{CHO}$ cells were transiently cotransfected with $\mathrm{NgR} 2-\mathrm{hFc}$ and a number of different Versican deletion constructs. Full-length Versican V3 and the G3 domain were readily coimmunoprecipitated with $\mathrm{NgR} 2-\mathrm{hFc}$ fusion protein but not in the control experiments with control hFc, or when $\mathrm{NgR} 2-\mathrm{hFc}$ was cotransfected with NogoB-myc (Fig. 9A,B). This result supports the specificity of the interaction and suggests that the G3 domain is sufficient for NgR2 binding.

In summary, our findings suggest that the NgR2/Versican interaction at the DEJ controls the density of epidermal fiber innervation by specifically suppressing branching and/or innervation of nonpeptidergic sensory afferents (Fig. 9C).

\section{Discussion}

Loss of NgR2 enhances innervation density of nonpeptidergic nociceptive fibers in epidermal skin

A striking finding of our study is the enhanced density of nonpeptidergic nerve endings in adult $\mathrm{NgR} 2^{-/-}$mouse footpad (Fig. 2 ), while density and projection of peptidergic fibers remain unaffected by NgR2 deficiency. Epidermal innervation density of nonpeptidergic nociceptive fibers in the mouse is largely regulated by the accessibility of GDNF GFLs present in the skin, whereas peptidergic fibers depend on NGF. Transgenic mice overexpressing GDNF in keratinocytes show a prominent hyperinnervation of nociceptive fibers in footpad epidermis (Zwick et al., 2002). Conversely, mice deficient in Ret or GDNF family receptor $\alpha 2$ (GFR $\alpha 2)$, the main coreceptor of Ret in nonpeptidergic neurons, display a drastic decrease in nonpeptidergic free nerve endings in footpad epidermis with no effect on peptidergic 

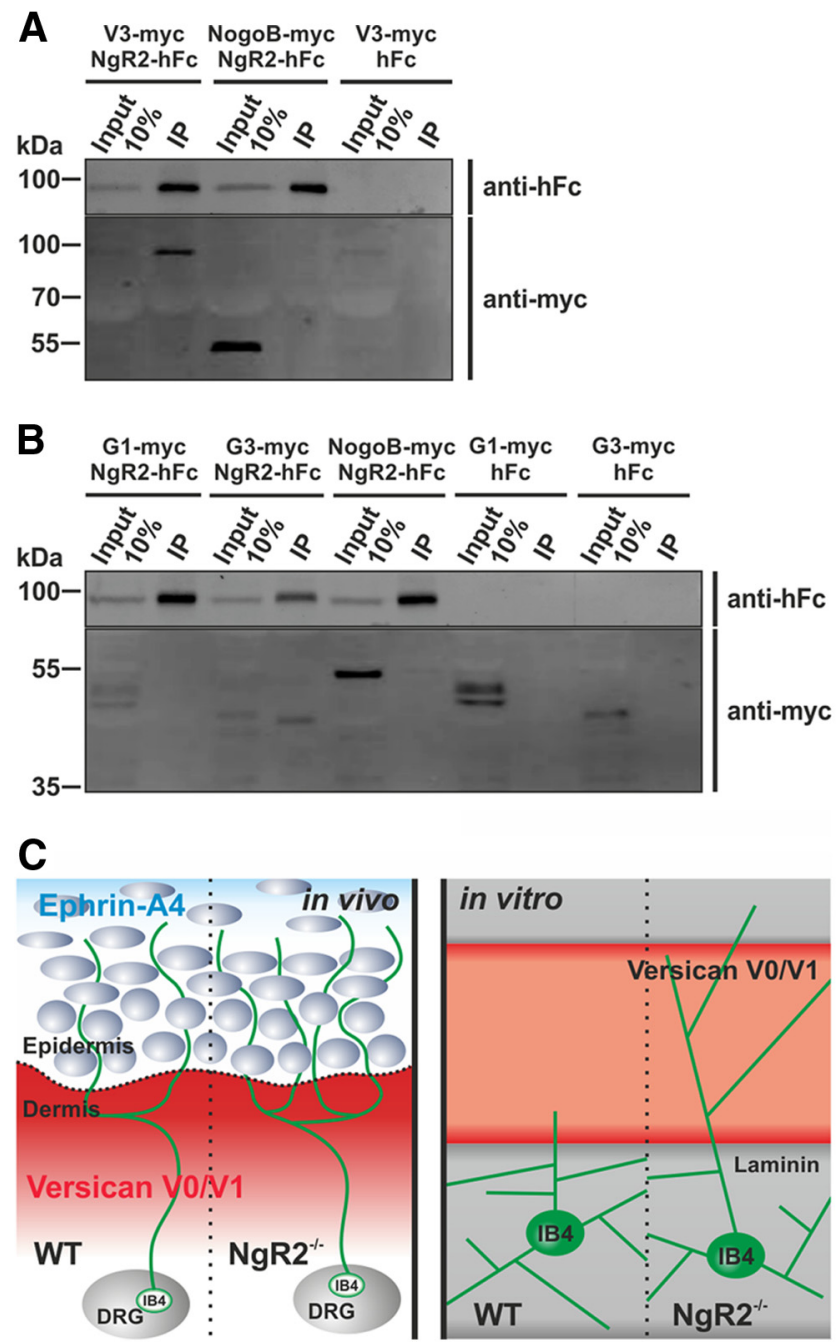

Figure 9. $\mathrm{NgR2}$ interacts with the $\mathrm{G} 3$ domain of Versican. $\boldsymbol{A}$, $\mathrm{CHO}$ cells were transiently transfected with $\mathrm{NgR2}$-hFc or pCMV-hFc together with V3-myc or NogoB-myc as indicated. Fc proteins were immunoprecipitated with Protein $A / G$ agarose. Western blot shows that $V 3-m y c$ coprecipitated with $\mathrm{NgR2}$-hFc. $\boldsymbol{B}$, CHO cells transiently transfected with $\mathrm{NgR2}-\mathrm{hFc}$, G1-myc, G3-myc, NogoB-myc, and pCMV-hFc as indicated were precipitated with Protein A/G agarose. Western blot shows that G3-myc but not G1-myc coprecipitated with NgR2-hFc. C, Schematic illustration of the in vivo and in vitro outgrowth phenotype of IB4 ${ }^{+} \mathrm{DRG}$ neurons in $\mathrm{NgR2} 2^{-1-}$ mice compared with WT controls.

innervation (Lindfors et al., 2006; Luo et al., 2007; Golden et al., 2010; Franck et al., 2011). Similarly, upregulation of trophic factors in skin diseases or following wound injuries stimulates axonal sprouting resulting in hyperinnervation (Tominaga et al., 2008). Likewise, overexpression of NTN in the skin results in hypersensitivity to cooling, a similar phenotype we found in $\mathrm{NgR} 2^{-1-}$ mice (Wang et al., 2013). However, mRNA expression levels for all of the growth factors tested and their respective receptors were comparable between $\mathrm{WT}$ and $\mathrm{NgR} 2^{-/-}$mice. Furthermore, consistent with a role for target-derived signals in the growth and maintenance of cell size in the DRG, adult DRGs from $\mathrm{NgR} 2^{-1-}$ mice are normal in size and show no change in the overall density of $\mathrm{IB}_{4}{ }^{+}$and $\mathrm{CGRP}^{+}$neurons or in their average somal diameter. Hence, it seems rather unlikely that hyperinnervation is the result of increased accessibility to GFLs or of modulation of the levels of critical growth factor receptors. We therefore conclude that NgR2 signaling at nerve terminals affects the ability of nonpeptidergic neurons to respond to factors in the skin that promote or inhibit axon extension and branching. Interestingly, the hyperinnervation phenotype seems to be target dependent, as the central projections of sensory DRGs are grossly normal in $\mathrm{NgR} 2^{-1-}$ mice. This suggests that the absence of $\mathrm{NgR} 2$ signaling does not change the responsiveness of sensory neurons to signals that regulate central terminal branching within the spinal cord. Branching of these central projections may depend upon the Slit family of guidance factors (Ma and Tessier-Lavigne, 2007 ) and Wnt family proteins for specifying the location of terminal arborization (Krylova et al., 2002).

\section{$\mathrm{NgR} 2$ is required to mediate sensitivity to Versican}

We show that skin-derived Versican is a novel interaction partner of NgR2 and is thus a likely candidate for controlling the density of nonpeptidergic fibers in the epidermis. Versican has a tridomain structure with an N-terminal region (G1 domain) responsible for binding hyaluronate, a central domain (G2) that carries the GAG side chains (GAG domain), and a C-terminal globular region (G3 domain) that interacts with simple carbohydrates and other proteins (Zimmermann and Ruoslahti, 1989). Alternative splicing generates four different isoforms of versican (V0 to V3; Fig. 7A; Dours-Zimmermann and Zimmermann, 1994). Versican V2 is primarily found in the CNS, while Versican V0 and V1, and in some species V3, are produced and secreted by proliferating basal keratinocytes and are the most prominent extracellular matrix proteoglycans at the DEJ (Zimmermann et al., 1994). In the developing nervous system Versican V0/V1 seems to act as barrier molecules affecting neural crest cell migration (Landolt et al., 1995; Dutt et al., 2006) and axonal growth of sensory neurons (Dutt et al., 2011). Our stripe-choice assays are consistent with this function. Nociceptive IB4-binding neurons deficient in NgR2 cross the border into the Versican-enriched lane more frequently and elaborate collaterals on this normally repulsive substrate. The effect was specific for Versican, and was not observed with EphrinA4, a repulsive guidance cue present in early postnatal epidermis (Moss et al., 2005) or for Aggrecan, a structurally closely related member of the hyalectan family (Bandtlow and Zimmermann, 2000). Previous studies have shown that the main inhibitory action of Aggrecan is mediated through its glycan chains and requires the previously identified CSPG receptors RPTP $\sigma$ and LAR (Shen et al., 2009; Fisher et al., 2011; Tan et al., 2011). However, NgR2 does not associate with chondroitin sulfate GAG chains (Dickendesher et al., 2012), and this explains the persistent sensitivity of NgR2 ${ }^{-/-}$ neurons to Aggrecan inhibition even at lower concentrations. In contrast to Aggrecan, the repulsive activity of Versican V0/V1 for sensory neurons is only partially released by Chondroitinase $\mathrm{ABC}$ treatment and has thus been mainly attributed to its protein core rather than to its GAG chains (Dutt et al., 2011), despite the lack of direct evidence. We now demonstrate that Versican V3, the smallest splice variant lacking GAGs, effectively repels sensory neurons in a dose-dependent manner and that loss of NgR2 is sufficient to abolish neurite inhibition even at higher Versican V3 concentrations. NgR2 seems to bind selectively to the C-terminal G3 domain, which is shared by all Versican variants, showing that interaction between NgR2 and Versicans does not depend on the presence of a GAG chain. Our findings also imply that Versican variants can act via different receptor complexes to elicit their repulsive effects: binding to NgR2 through the G3 domain and/or to CSPG receptors through the GAG chains. It is conceivable that axons of specific sensory subclasses may respond differentially 
to Versicans, depending on their composition of their Versican receptors. Our observation of striking cell-type-specific differences in the sensitivity to Versican V3 in vitro is consistent with this interpretation. IB4-binding neurons were strongly repelled by V3, whereas peptidergic neurons were only moderately affected and large $\mathrm{NF} 200^{+}$neurons seemed to be insensitive, although the vast majority of them express NgR2-mRNA, which on first sight does not seem consistent with the idea that $\mathrm{NgR} 2$ and Versican represent a ligandreceptor pair. The discrepancy may be explained by the fact that not all peptidergic neurons express NgR2. In addition, we do not know the actual levels of NgR2 receptor proteins on DRG axons from different subclasses, so it is unclear whether this phenotype results from a reduced NgR2 surface expression or from a lack of potential coreceptors required for NgR2signaling. The $\mathrm{NgR}$ receptor complex contains both, the $\mathrm{NgR}$ and either the neurotrophin receptor $\mathrm{p} 75^{\mathrm{NTR}}$ or the orphan receptor TNF family member TROY (Mironova and Giger, 2013), but the functional signaling partner for NgR2 in sensory DRG neurons is currently unknown. A recent study suggests that NgR2 associates with TROY to limit synapse formation of hippocampal neurons in vitro (Wills et al., 2012). TROY seems to be expressed by all subclasses of DRG neurons (Park et al., 2005), whereas at postnatal stages p $75^{\text {NTR }}$ is expressed exclusively by IB4-negative sensory neurons (Molliver and Snider, 1997). Our results clearly indicate that IB4 ${ }^{+}$axons display increased sensitivity to V3-induced repulsion compared with $\mathrm{IB} 4^{-/} \mathrm{NF} 200^{-}$axons, which correlates with the selective increase of nonpeptidergic fibers in vivo. Furthermore, the fact that the density of CGRP ${ }^{+}$and NF $200^{+}$fibers is not increased in the NgR2-null background indicates that additional signals restrict the penetration of sensory fibers in the epidermis and/or suppress terminal arborization. A decreased production of Sema3A by atopic keratinocytes has been suggested to account for the hyperinnervation of CGRP ${ }^{+}$fibers in atopic eczema (Tominaga et al., 2008).

\section{$\mathrm{NgR2}{ }^{-/-}$mice exhibit sensory defects}

Our results are similar to those in a recent report identifying Laminin-332, another major component of the dermo-epidermal skin basement membrane, as a local suppressor of sensory terminal branching and mechanosensitivity currents, a function it exerts by preventing the formation of protein tethers (Chiang et al., 2011). In combination with our data these findings show that the matrix environments between dermis and epidermis are distinct and may act as important barriers to control the branching of specific subtypes of sensory afferents. Whether Versican exerts modulatory effects on the mechanosensitivity of sensory neurons, as shown for Laminin-322, remains to be determined. Deletion of NgR2 significantly increased acute mechanical sensitivity but not heat sensitivity. The lack of a deficit in sensing heat pain is interesting given the polymodal properties of many nociceptive neurons (Jankowski et al., 2012) but is consistent with our finding that the number of $\mathrm{TrpV} 1^{+}$neurons and its expression are unaffected by NgR2 deficiency. Whether the increased density of nonpeptidergic afferents contributes to the increased mechanical sensitivity we observed in $\mathrm{NgR}^{-1-}$ mice is presently unclear. However, greater axonal branching may result in greater summation of depolarizing potentials evoked by local factors. Since our results did not appear to show much change of known mechanosensors at the transcriptional level in the DRG, further studies are required to reveal whether the enhanced mechanosensitivity might instead be due to alterations in the localization or composition of mechanosensors and/or central processing of mechanical signals.

In summary, we report a novel role for $\mathrm{NgR} 2$ as a suppressor of terminal branching of nociceptive nonpeptidergic afferents during epidermal innervation. Loss of NgR2 leads to increased innervation of sensory endings in the epidermis, associated with a hypersensitivity to mechanical pain and cold sensation. Combined with the recent findings that NgR1 is an important stabilizer of neuronal connectivity in the brain, the identification of $\mathrm{NgR} 2$ as a receptor for Versican variants provides insights into the function of these molecules in the CNS and peripheral nervous system.

\section{References}

Albers KM, Woodbury CJ, Ritter AM, Davis BM, Koerber HR (2006) Glial cell-line-derived neurotrophic factor expression in skin alters the mechanical sensitivity of cutaneous nociceptors. J Neurosci 26:2981-2990. CrossRef Medline

Bandtlow CE, Zimmermann DR (2000) Proteoglycans in the developing brain: new conceptual insights for old proteins. Physiol Rev 80:12671290. Medline

Banerjee B, Medda BK, Schmidt J, Zheng Y, Zhang Z, Shaker R, Sengupta JN (2009) Altered expression of P2X3 in vagal and spinal afferents following esophagitis in rats. Histochem Cell Biol 132:585-597. CrossRef Medline

Basbaum AI, Bautista DM, Scherrer G, Julius D (2009) Cellular and molecular mechanisms of pain. Cell 139:267-284. CrossRef Medline

Bautista DM, Siemens J, Glazer JM, Tsuruda PR, Basbaum AI, Stucky CL, Jordt SE, Julius D (2007) The menthol receptor TRPM8 is the principal detector of environmental cold. Nature 448:204-208. CrossRef Medline

Bogen O, Joseph EK, Chen X, Levine JD (2008) GDNF hyperalgesia is mediated by PLCgamma, MAPK/ERK, PI3K, CDK5 and Src family kinase signaling and dependent on the IB4-binding protein versican. Eur J Neurosci 28:12-19. CrossRef Medline

Borisoff JF, Chan CC, Hiebert GW, Oschipok L, Robertson GS, Zamboni R, Steeves JD, Tetzlaff W (2003) Suppression of Rho-kinase activity promotes axonal growth on inhibitory CNS substrates. Mol Cell Neurosci 22:405-416. CrossRef Medline

Bourane S, Méchaly I, Venteo S, Garces A, Fichard A, Valmier J, Carroll P (2007) A SAGE-based screen for genes expressed in sub-populations of neurons in the mouse dorsal root ganglion. BMC Neurosci 8:97. CrossRef Medline

Chiang LY, Poole K, Oliveira BE, Duarte N, Sierra YA, Bruckner-Tuderman L, Koch M, Hu J, Lewin GR (2011) Laminin-332 coordinates mechanotransduction and growth cone bifurcation in sensory neurons. Nat Neurosci 14:993-1000. CrossRef Medline

Colburn RW, Lubin ML, Stone DJ Jr, Wang Y, Lawrence D, D’Andrea MR, Brandt MR, Liu Y, Flores CM, Qin N (2007) Attenuated cold sensitivity in TRPM8 null mice. Neuron 54:379-386. CrossRef Medline

da Costa DS, Meotti FC, Andrade EL, Leal PC, Motta EM, Calixto JB (2010) The involvement of the transient receptor potential Al (TRPA1) in the maintenance of mechanical and cold hyperalgesia in persistent inflammation. Pain 148:431-437. CrossRef Medline

Dickendesher TL, Baldwin KT, Mironova YA, Koriyama Y, Raiker SJ, Askew KL, Wood A, Geoffroy CG, Zheng B, Liepmann CD, Katagiri Y, Benowitz LI, Geller HM, Giger RJ (2012) NgR1 and NgR3 are receptors for chondroitin sulfate proteoglycans. Nat Neurosci 15:703-712. CrossRef Medline

Dours-Zimmermann MT, Zimmermann DR (1994) A novel glycosaminoglycan attachment domain identified in two alternative splice variants of human versican. J Biol Chem 269:32992-32998. Medline

Dours-Zimmermann MT, Maurer K, Rauch U, Stoffel W, Fässler R, Zimmermann DR (2009) Versican V2 assembles the extracellular matrix surrounding the nodes of ranvier in the CNS. J Neurosci 29:7731-7742. CrossRef Medline

Duggan A, Garcia-Anoveros J, Corey DP (2002) The PDZ domain protein PICK1 and the sodium channel $\mathrm{BNaC1}$ interact and localize at mechanosensory terminals of dorsal root ganglion neurons and dendrites of central neurons. J Biol Chem 277:5203-5208. CrossRef Medline

Dutt S, Kléber M, Matasci M, Sommer L, Zimmermann DR (2006) Versican 
V0 and V1 guide migratory neural crest cells. J Biol Chem 281:1212312131. CrossRef Medline

Dutt S, Cassoly E, Dours-Zimmermann MT, Matasci M, Stoeckli ET, Zimmermann DR (2011) Versican V0 and V1 direct the growth of peripheral axons in the developing chick hindlimb. J Neurosci 31:5262-5270. CrossRef Medline

Fisher D, Xing B, Dill J, Li H, Hoang HH, Zhao Z, Yang XL, Bachoo R, Cannon S, Longo FM, Sheng M, Silver J, Li S (2011) Leukocyte common antigen-related phosphatase is a functional receptor for chondroitin sulfate proteoglycan axon growth inhibitors. J Neurosci 31:14051-14066. CrossRef Medline

Fournier AE, GrandPre T, Strittmatter SM (2001) Identification of a receptor mediating Nogo-66 inhibition of axonal regeneration. Nature 409: 341-346. CrossRef Medline

Franck MC, Stenqvist A, Li L, Hao J, Usoskin D, Xu X, Wiesenfeld-Hallin Z, Ernfors P (2011) Essential role of Ret for defining nonpeptidergic nociceptor phenotypes and functions in the adult mouse. Eur J Neurosci 33:1385-1400. CrossRef Medline

García-Añoveros J, Samad TA, Zuvela-Jelaska L, Woolf CJ, Corey DP (2001) Transport and localization of the $\mathrm{DEG} / \mathrm{ENaC}$ ion channel $\mathrm{BNaCl}$ alpha to peripheral mechanosensory terminals of dorsal root ganglia neurons. J Neurosci 21:2678-2686. Medline

Golden JP, Hoshi M, Nassar MA, Enomoto H, Wood JN, Milbrandt J, Gereau RW 4th, Johnson EM Jr, Jain S (2010) RET signaling is required for survival and normal function of nonpeptidergic nociceptors. J Neurosci 30:3983-3994. CrossRef Medline

Hattori T, Chen J, Harding AM, Price MP, Lu Y, Abboud FM, Benson CJ (2009) ASIC2a and ASIC3 heteromultimerize to form $\mathrm{pH}$-sensitive channels in mouse cardiac dorsal root ganglia neurons. Circ Res 105:279286. CrossRef Medline

Hsieh YL, Chiang H, Lue JH, Hsieh ST (2012) P2X3-mediated peripheral sensitization of neuropathic pain in resiniferatoxin-induced neuropathy. Exp Neurol 235:316-325. CrossRef Medline

Jankowski MP, Lawson JJ, McIlwrath SL, Rau KK, Anderson CE, Albers KM, Koerber HR (2009) Sensitization of cutaneous nociceptors after nerve transection and regeneration: possible role of target-derived neurotrophic factor signaling. J Neurosci 29:1636-1647. CrossRef Medline

Jankowski MP, Soneji DJ, Ekmann KM, Anderson CE, Koerber HR (2012) Dynamic changes in heat transducing channel TRPV1 expression regulate mechanically insensitive, heat sensitive C-fiber recruitment after axotomy and regeneration. J Neurosci 32:17869-17873. CrossRef Medline

Kojima N, Saito H, Nishikawa M, Yuri S, Jo OD, Pham PC, Yanagawa N (2011) Lithium induces c-Ret expression in mouse inner medullary collecting duct cells. Cell Signal 23:371-379. CrossRef Medline

Krylova O, Herreros J, Cleverley KE, Ehler E, Henriquez JP, Hughes SM, Salinas PC (2002) WNT-3, expressed by motoneurons, regulates terminal arborization of neurotrophin-3-responsive spinal sensory neurons. Neuron 35:1043-1056. CrossRef Medline

Lagerström MC, Rogoz K, Abrahamsen B, Lind AL, Olund C, Smith C, Mendez JA, Wallén-Mackenzie A, Wood JN, Kullander K (2011) A sensory subpopulation depends on vesicular glutamate transporter 2 for mechanical pain, and together with substance P, inflammatory pain. Proc Natl Acad Sci U S A 108:5789-5794. CrossRef Medline

Landolt RM, Vaughan L, Winterhalter KH, Zimmermann DR (1995) Versican is selectively expressed in embryonic tissues that act as barriers to neural crest cell migration and axon outgrowth. Development 121:23032312. Medline

Laurén J, Airaksinen MS, Saarma M, Timmusk T (2003) Two novel mammalian nogo receptor homologs differentially expressed in the central and peripheral nervous systems. Mol Cell Neurosci 24:581-594. CrossRef Medline

Lindfors PH, Vöikar V, Rossi J, Airaksinen MS (2006) Deficient nonpeptidergic epidermis innervation and reduced inflammatory pain in glial cell line-derived neurotrophic factor family receptor alpha2 knock-out mice. J Neurosci 26:1953-1960. CrossRef Medline

Livak KJ, Schmittgen TD (2001) Analysis of relative gene expression data using real-time quantitative PCR and the 2(-Delta Delta C(T)) Method. Methods 25:402-408. CrossRef Medline

Luo W, Wickramasinghe SR, Savitt JM, Griffin JW, Dawson TM, Ginty DD (2007) A hierarchical NGF signaling cascade controls Ret-dependent and Ret-independent events during development of nonpeptidergic DRG neurons. Neuron 54:739-754. CrossRef Medline
Ma L, Tessier-Lavigne M (2007) Dual branch-promoting and branchrepelling actions of Slit/Robo signaling on peripheral and central branches of developing sensory axons. J Neurosci 27:6843-6851. CrossRef Medline

Malgouries S, Thibaut S, Bernard BA (2008) Proteoglycan expression patterns in human hair follicle. Br J Dermatol 158:234-242. Medline

Marthiens V, Gavard J, Padilla F, Monnet C, Castellani V, Lambert M, Mège RM (2005) A novel function for cadherin-11 in the regulation of motor axon elongation and fasciculation. Mol Cell Neurosci 28:715-726. CrossRef Medline

Mironova YA, Giger RJ (2013) Where no synapses go: gatekeepers of circuit remodeling and synaptic strength. Trends Neurosci 36:363-373. CrossRef Medline

Molliver DC, Snider WD (1997) Nerve growth factor receptor TrkA is down-regulated during postnatal development by a subset of dorsal root ganglion neurons. J Comp Neurol 381:428-438. CrossRef Medline

Molliver DC, Radeke MJ, Feinstein SC, Snider WD (1995) Presence or absence of TrkA protein distinguishes subsets of small sensory neurons with unique cytochemical characteristics and dorsal horn projections. J Comp Neurol 361:404-416. CrossRef Medline

Moss A, Alvares D, Meredith-Middleton J, Robinson M, Slater R, Hunt SP, Fitzgerald M (2005) Ephrin-A4 inhibits sensory neurite outgrowth and is regulated by neonatal skin wounding. Eur J Neurosci 22:2413-2421. CrossRef Medline

Niederöst B, Oertle T, Fritsche J, McKinney RA, Bandtlow CE (2002) Nogo-A and myelin-associated glycoprotein mediate neurite growth inhibition by antagonistic regulation of RhoA and Racl. J Neurosci 22: 10368-10376. Medline

Oertle T, van der Haar ME, Bandtlow CE, Robeva A, Burfeind P, Buss A, Huber AB, Simonen M, Schnell L, Brösamle C, Kaupmann K, Vallon R, Schwab ME (2003) Nogo-A inhibits neurite outgrowth and cell spreading with three discrete regions. J Neurosci 23:5393-5406. Medline

Park JB, Yiu G, Kaneko S, Wang J, Chang J, He XL, Garcia KC, He Z (2005) A TNF receptor family member, TROY, is a coreceptor with Nogo receptor in mediating the inhibitory activity of myelin inhibitors. Neuron 45: 345-351. CrossRef Medline

Peters EM, Botchkarev VA, Müller-Röver S, Moll I, Rice FL, Paus R (2002) Developmental timing of hair follicle and dorsal skin innervation in mice. J Comp Neurol 448:28-52. CrossRef Medline

Price MP, Lewin GR, McIlwrath SL, Cheng C, Xie J, Heppenstall PA, Stucky CL, Mannsfeldt AG, Brennan TJ, Drummond HA, Qiao J, Benson CJ, Tarr DE, Hrstka RF, Yang B, Williamson RA, Welsh MJ (2000) The mammalian sodium channel BNC1 is required for normal touch sensation. Nature 407:1007-1011. CrossRef Medline

Price MP, McIlwrath SL, Xie J, Cheng C, Qiao J, Tarr DE, Sluka KA, Brennan TJ, Lewin GR, Welsh MJ (2001) The DRASIC cation channel contributes to the detection of cutaneous touch and acid stimuli in mice. Neuron 32:1071-1083. CrossRef Medline

Priestley JV, Michael GJ, Averill S, Liu M, Willmott N (2002) Regulation of nociceptive neurons by nerve growth factor and glial cell line derived neurotrophic factor. Can J Physiol Pharmacol 80:495-505. CrossRef Medline

Schweigreiter R, Walmsley AR, Niederöst B, Zimmermann DR, Oertle T, Casademunt E, Frentzel S, Dechant G, Mir A, Bandtlow CE (2004) Versican V2 and the central inhibitory domain of Nogo-A inhibit neurite growth via p75NTR/NgR-independent pathways that converge at RhoA. Mol Cell Neurosci 27:163-174. CrossRef Medline

Shen Y, Tenney AP, Busch SA, Horn KP, Cuascut FX, Liu K, He Z, Silver J, Flanagan JG (2009) PTPsigma is a receptor for chondroitin sulfate proteoglycan, an inhibitor of neural regeneration. Science 326:592-596. CrossRef Medline

Sherwood TW, Lee KG, Gormley MG, Askwith CC (2011) Heteromeric acid-sensing ion channels (ASICs) composed of ASIC2b and ASIC1a display novel channel properties and contribute to acidosis-induced neuronal death. J Neurosci 31:9723-9734. CrossRef Medline

Tan CL, Kwok JC, Patani R, Ffrench-Constant C, Chandran S, Fawcett JW (2011) Integrin activation promotes axon growth on inhibitory chondroitin sulfate proteoglycans by enhancing integrin signaling. J Neurosci 31:6289-6295. CrossRef Medline

Tominaga M, Ogawa H, Takamori K (2008) Decreased production of semaphorin 3A in the lesional skin of atopic dermatitis. Br J Dermatol 158:842844. CrossRef Medline 
Venkatesh K, Chivatakarn O, Lee H, Joshi PS, Kantor DB, Newman BA, Mage R, Rader C, Giger RJ (2005) The Nogo-66 receptor homolog NgR2 is a sialic acid-dependent receptor selective for myelin-associated glycoprotein. J Neurosci 25:808-822. CrossRef Medline

Wang KC, Koprivica V, Kim JA, Sivasankaran R, Guo Y, Neve RL, He Z (2002) Oligodendrocyte-myelin glycoprotein is a Nogo receptor ligand that inhibits neurite outgrowth. Nature 417:941-944. CrossRef Medline

Wang T, Jing X, DeBerry JJ, Schwartz ES, Molliver DC, Albers KM, Davis BM (2013) Neurturin overexpression in skin enhances expression of TRPM8 in cutaneous sensory neurons and leads to behavioral sensitivity to cool and menthol. J Neurosci 33:2060-2070. CrossRef Medline

Wills ZP, Mandel-Brehm C, Mardinly AR, McCord AE, Giger RJ, Greenberg ME (2012) The nogo receptor family restricts synapse number in the developing hippocampus. Neuron 73:466-481. CrossRef Medline

Wörter V, Schweigreiter R, Kinzel B, Mueller M, Barske C, Böck G, Frentzel S, Bandtlow CE (2009) Inhibitory activity of myelin-associated glycoprotein on sensory neurons is largely independent of $\mathrm{NgR} 1$ and $\mathrm{NgR} 2$ and resides within Ig-Like domains 4 and 5. PLoS One 4:e5218. CrossRef Medline

Xu GY, Shenoy M, Winston JH, Mittal S, Pasricha PJ (2008) P2X receptor- mediated visceral hyperalgesia in a rat model of chronic visceral hypersensitivity. Gut 57:1230-1237. CrossRef Medline

Zako M, Shinomura T, Ujita M, Ito K, Kimata K (1995) Expression of PG$\mathrm{M}(\mathrm{V} 3)$, an alternatively spliced form of PG-M without a chondroitin sulfate attachment in region in mouse and human tissues. J Biol Chem 270:3914-3918. CrossRef Medline

Zimmermann DR, Ruoslahti E (1989) Multiple domains of the large fibroblast proteoglycan, versican. EMBO J 8:2975-2981. Medline

Zimmermann DR, Dours-Zimmermann MT, Schubert M, BrucknerTuderman L (1994) Versican is expressed in the proliferating zone in the epidermis and in association with the elastic network of the dermis. J Cell Biol 124:817-825. CrossRef Medline

Zwick M, Davis BM, Woodbury CJ, Burkett JN, Koerber HR, Simpson JF, Albers KM (2002) Glial cell line-derived neurotrophic factor is a survival factor for isolectin B4-positive, but not vanilloid receptor 1-positive, neurons in the mouse. J Neurosci 22:4057-4065. Medline

Zylka MJ, Rice FL, Anderson DJ (2005) Topographically distinct epidermal nociceptive circuits revealed by axonal tracers targeted to Mrgprd. Neuron 45:17-25. CrossRef Medline 